\title{
Microbiome diversity declines while distinct expansions of Th17, iNKT, and dendritic cell subpopulations emerge after anastomosis surgery
}

\author{
Emilie E. Vomhof-DeKrey ${ }^{1,2^{*}}$ (D) , Allie Stover ${ }^{2}$ and Marc D. Basson ${ }^{1,2,3^{*}}$ (1)
}

\begin{abstract}
Background: Anastomotic failure causes morbidity and mortality even in technically correct anastomoses. Initial leaks must be prevented by mucosal reapproximation across the anastomosis. Healing is a concerted effort between intestinal epithelial cells (IECs), immune cells, and commensal bacteria. IEC TLR4 activation and signaling is required for mucosal healing, leading to inflammatory factor release that recruits immune cells to limit bacteria invasion. TLR4 absence leads to mucosal damage from loss in epithelial proliferation, attenuated inflammatory response, and bacteria translocation. We hypothesize after anastomosis, an imbalance in microbiota will occur due to a decrease in TLR4 expression and will lead to changes in the immune milieu.
\end{abstract}

Results: We isolated fecal content and small intestinal leukocytes from murine, Roux-en-Y and end-to-end anastomoses, to identify microbiome changes and subsequent alterations in the regulatory and pro-inflammatory immune cells 3 days post-operative. TLR4 ${ }^{+}$IECs were impaired after anastomosis. Microbiome diversity was reduced, with Firmicutes, Bacteroidetes, and Saccharibacteria decreased and Proteobacteria increased. A distinct TCR $\beta^{\text {hi }} \mathrm{CD} 4^{+} \mathrm{T}$ cells subset after anastomosis was 10-20-fold greater than in control mice. 84\% were Th17 IL-17A/F $\mathrm{IL}^{+} 22^{+}$and/or TNFa+

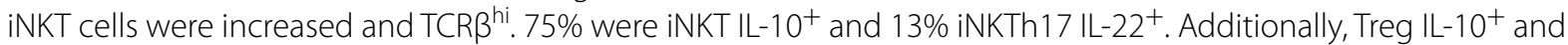
$\mathrm{IL}-22^{+}$cells were increased. A novel dendritic cell subset was identified in anastomotic regions that was CD $11 \mathrm{~b}^{\text {hi }}$ CD103 ${ }^{\text {mid }}$ and was $93 \% \mathrm{IL}-10^{+}$.

Conclusions: This anastomotic study demonstrated a decrease in IEC TLR4 expression and microbiome diversity which then coincided with increased expansion of regulatory and pro-inflammatory immune cells and cytokines. Defining the anastomotic mucosal environment could help inform innovative therapeutics to target excessive proinflammatory invasion and microbiome imbalance.

Keywords: Immune-microbiota crosstalk, Mucosal healing, Toll-like receptors, CD1 1 b hi $^{\text {CD103 }} 3^{\text {mid }}$

\footnotetext{
*Correspondence: emilie.dekrey@med.und.edu; marc.basson@und.edu ${ }^{1}$ Department of Surgery, University of North Dakota School of Medicine and the Health Sciences, 1301 North Columbia Road, Stop 9037, Grand Forks, ND 58202, USA

Full list of author information is available at the end of the article
}

\begin{abstract}
Background
Anastomotic failure is one of the most serious complications of intestinal surgery [24]. An anastomotic leak can lead to high morbidity, increased mortality, and considerable added hospital costs [18]. Even with extensive research and surgical technique improvements, small intestinal and colorectal anastomosis leakage can occur in $0.05-30 \%$ of operations $[18,24,30,31,43]$. Anastomotic
\end{abstract} original author(s) and the source, provide a link to the Creative Commons licence, and indicate if changes were made. The images or other third party material in this article are included in the article's Creative Commons licence, unless indicated otherwise in a credit line to the material. If material is not included in the article's Creative Commons licence and your intended use is not permitted by statutory regulation or exceeds the permitted use, you will need to obtain permission directly from the copyright holder. To view a copy of this licence, visit http://creativecommons.org/licenses/by/4.0/. The Creative Commons Public Domain Dedication waiver (http://creativeco mmons.org/publicdomain/zero/1.0/) applies to the data made available in this article, unless otherwise stated in a credit line to the data. 
leakage can vary in its onset of occurrence. An early leak within the first to second postoperative days occurs most often because of technical reasons, whereas a latent leak occurring by the end of the first postoperative week is most often attributed to a failure in the normal healing mechanisms [43].

Proper intestinal healing requires a coordinated crosstalk between intestinal epithelial cells (IECs), immune cells, and microbiome. The multifaceted toll-like receptor (TLR) signaling pathways serve as an interface for concerted crosstalk between the intestinal epithelial barrier, microbiota, and immune system [14]. The TLR signaling pathways help to maintain a constant homeostatic regulation of microbial load and the immune response. There are 10 total TLRs, and they are expressed on macrophages, dendritic cells (DCs), $\mathrm{T}$ lymphocytes, and IECs [14]. TLR4 is expressed in the apical region of the terminal ileum of mice [1]. TLR4 signaling is required for induction of mucosal healing pathways, the defense against gram-negative bacteria, and maintaining the tolerance to commensal bacteria. During mucosal injury, TLR4 activation on IECs leads to the release of inflammatory cytokines (i.e., IL-8) and chemokines that recruit innate and adaptive immune cells to limit bacterial invasion. TLR4 absence can lead to severe mucosal damage from a loss in epithelial proliferation, impaired inflammatory response, and bacterial translocation. However, TLR4 signaling needs to be tightly regulated as prolonged activation can result in detrimental inflammation that inhibits mucosal repair through decreased enterocyte proliferation and migration [14].

Many immune cell types function alongside gut microbiota to promote mucosal healing in the steady state and during injury. These include $\mathrm{CD} 103^{+}$conventional DCs (cDCs), Th17 cells, $\mathrm{T}$ regulatory (Treg) cells, iNKT, and iNKTh17 cells [24]. Typically, the gut microbiota induces differentiation of these immune cells. Treg and iNKT cells will undergo differentiation and secrete the antiinflammatory cytokine, IL-10, through interactions with Clostridia [25]. The promotion of $\mathrm{CD} 4^{+} \mathrm{T}$ cells to Th17 cells can be induced by segmented filamentous bacteria (SFB) and Th17 and iNKTh17 cells will produce IL-17a, IL-17f, and IL-22, which is a key cytokine that acts on IL$22 \mathrm{R}$ only on epithelial cells in order to promote healing [25]. However, there is a dichotomy to this system, if SFB colonization it too expressive, systemic Th17 activation will result in increased inflammation and mucosal injury $[25,56]$. Therefore, the IL- 10 signaling of $\mathrm{CD} 103^{+} \mathrm{DCs}$ and Tregs are key to helping to regulate the Th17 activation [40]. Transforming growth factor- $\beta$ drives the formation of Th17 cells from naïve $\mathrm{T}$ cells [34]. Th17 cells are known to produce cytokines IL-17 and IL-22 which have several roles in the gastrointestinal tract, such as cell proliferation, tissue regeneration, pathogen defense, and intestinal barrier maintenance and protection [22, 34]. IL-22 promotes production of innate antimicrobial molecules, like defensins, Reg family molecules, and S100 proteins by IECs [34]. Additionally, the intestinal epithelial barrier is maintained via a cross talk between IL-22, innate lymphoid cells type 3 , and microbiota.

iNKT cells are subgroup of unconventional, CD1drestricted $\mathrm{T}$ cells that have TCRs and are able to recognize endogenous and exogenous lipids, such as $\alpha$ GalCer, which are presented by the surface molecule CD1d in mice (CD1 in humans) [44]. After iNKT cell activation, copious amounts of cytokines such as IL-4, IL-10, and IL-22 are secreted to regulate the downstream activation of DCs, NK cells, B cells, or conventional T cells. Recently, there has been growing evidence that iNKT cells play a central role in governing the bidirectional interactions of the host cells and the commensal microbiota, which is key to intestinal homeostasis and preventing inflammation [13]. The modulation of the mucosal immunity and regulation of bacterial colonization is through iNKT cells recognizing the presentation of commensal-derived lipids by CD1d that is expressed on B cells, DCs, macrophages, IECs, and innate lymphoid cells $[4,13,32,33,42,44,47,53]$. Despite all of the research that has been done to demonstrate intestinal iNKT cell function in intestinal homeostasis, there is still much that remains to be determined as to how iNKT cells populations adjust after intestinal surgery and how these changes correlate to changes in the intestinal commensal bacteria.

$\mathrm{CD}_{103^{+}}$DCs are a heterogeneous population and can be categorized into two subsets based on their expression of CD11b. Both populations, $\mathrm{CD}_{103^{+}} \mathrm{CD}^{\mathrm{C}} 1 \mathrm{~b}^{+}$and $\mathrm{CD}_{103}{ }^{+} \mathrm{CD}_{11 \mathrm{~b}^{-}}$are found in the small intestinal lamina propria and intestinal lymph, but $\mathrm{CD}_{103}{ }^{+} \mathrm{CD} 11 \mathrm{~b}^{+}$make up the majority of the population found in the lamina propria $[8,15,20]$. The $\mathrm{CD}_{103^{+}} \mathrm{DCs}$ are tolerogenic and are able to induce the differentiation of naïve $\mathrm{T}$ cells to FoxP3 $^{+}$Treg cells, while $\mathrm{CD} 103^{-}$DCs are not toleragenic $[8,11,49]$. The intestinal $\mathrm{CD} 103^{+} \mathrm{DC}$ induction of Treg differentiation is dependent on retinoic acid and active transforming growth factor (TGF) $b[8,11,49]$.

In this study, we performed two types of anastomosis surgeries on C57BL/6 wildtype mice, Roux-en-Y and end-to-end anastomoses. The focus of this manuscript is to discern the correlative relationship of the microbiota and immune system early after an anastomosis operation. We chose to evaluate these parameters at 3 days post-operative as this is the time when a latent leak could become clinically apparent [43]. Dissecting the regulatory mechanisms of mucosal healing could impact therapeutic treatments given after an anastomotic operation. 


\section{Methods}

\section{Mice and surgery}

Female C57Bl/6J mice, 7-14 weeks of age, were acquired from Jackson Laboratories (Bar Harbor, Maine) and bred at UND. These studies were performed according to protocol \#1708-1 that was approved by the University of North Dakota Institutional Animal Care and Use Committee. Liquid diet (Vivonex Pediatric) was given to mice undergoing surgery $72 \mathrm{~h}$ prior to and the 3 days after surgery. For pain relief, $1-2 \mathrm{mg} / \mathrm{kg}$ of buprenorphinesustained release was injected subcutaneously. Mice were anesthetized with 1-2\% isoflurane and a laparotomy was performed. An end-to-end or Roux-en-Y anastomosis was made starting $5 \mathrm{~cm}$ from the pyloric orifice of the stomach using 8-0 Nylon suture (Unify, ADSurgical, black thread, taper point, $3 / 86.4 \mathrm{~mm}$ curved needle) (Fig. 1) [52]. The Roux-en-Y limb was approximately 2-3 cm long. A 5-0 Polysorb Braided Absorbable suture (Coviden, 18", $45 \mathrm{~cm}$, undyed, P-12 cutting 3/8 $19 \mathrm{~mm}$ needle, curved) was used to suture the body cavity and a 3-0 Perma-hand silk thread (Ethicon, black braided, $30^{\prime \prime} \mathrm{KS} 60 \mathrm{~mm}$ straight, reverse cutting needle) was used to suture the skin. Mice were euthanized 3 days after surgery, intestinal fecal content and intestinal regions were harvested from the duodenum (A), jejunum (B), and ileum $(\mathrm{C})$ as laid out in Fig. 1.

\section{Intestinal epithelial cell isolation}

We isolated the intestinal cells using a protocol similar to Goodyear et al. [16]. Intestinal regions were cut open longitudinally and cut into $2 \mathrm{~cm}$ pieces and placed in a $50 \mathrm{ml}$ tube with $10 \mathrm{ml}$ complete RPMI (cRPMI: $500 \mathrm{ml}$ RPMI, 10\% FBS, $2 \mathrm{mM}$ L-glutamine, $1 \mathrm{mM}$ sodium pyruvate, 1 $\times$ non-essential amino acids, and PSEPx $=100$ units $/ \mathrm{ml}$ penicillin, $100 \mu \mathrm{g} / \mathrm{ml}$ streptomycin, $25 \mu \mathrm{g} / \mathrm{ml}$ enrofloxacin, 100 units/ml polymyxin B (RPMI \& FBS, Genesee Scientific, Cajon, CA; all other cRMPI components from Millipore Sigma, St. Louis, MO). Mucus was removed by washing tissue with Solution 1 ( $5 \mathrm{mM}$ DTT in HBSS (Millipore Sigma) + PSEPx $+2 \%$ FBS) at $37{ }^{\circ} \mathrm{C}$ with $20 \mathrm{ml} / \mathrm{g}$ tissue for $20 \mathrm{~min} / \mathrm{g}$ tissue with $200 \mathrm{rpm}$ shaking. This wash was discarded and then the epithelial layer was collected with 3 washes at $37^{\circ} \mathrm{C}$ of Solution $2(5 \mathrm{mM}$ EDTA in HBSS + PSEPx + 2\% FBS) using $15 \mathrm{ml} / \mathrm{g}$ of tissue for $15 \mathrm{~min} / \mathrm{g}$ of tissue and $200 \mathrm{rpm}$ shaking. Each wash was collected in a $50 \mathrm{ml}$ tube and stored on ice to

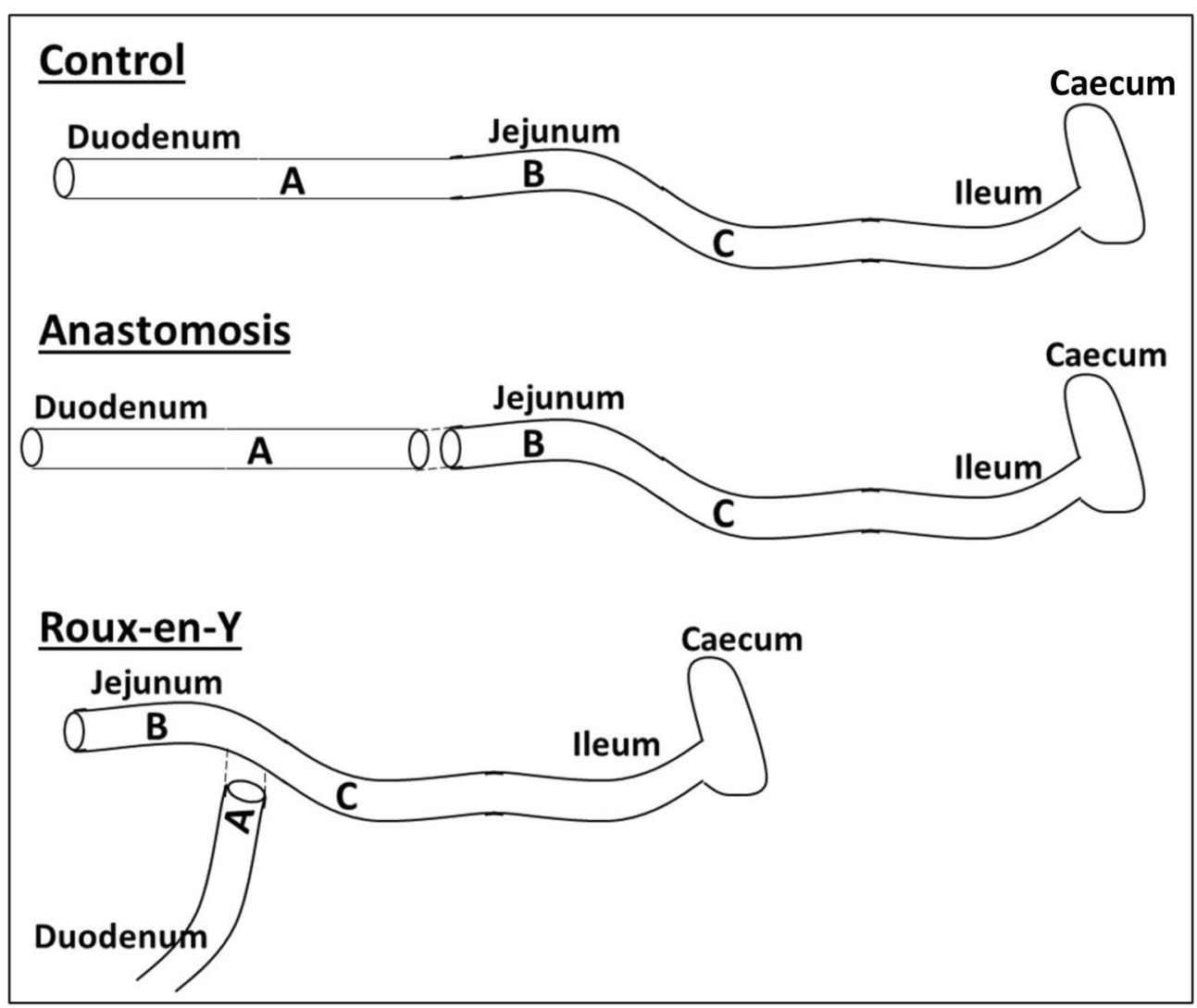

Fig. 1 Surgical pictograms with intestinal segments labelled A-distal duodenum, B-jejunum/limb, and C-proximal ileum 
combine with the lamina propria cells after the next step. The tissue was then washed with $10 \mathrm{ml}$ Solution 3 (HBSS + PSEPx +10 mM HEPES) for 10 min with $200 \mathrm{rpm}$ shaking in order to remove the FBS and EDTA, this solution was discarded after this wash. To collect a lamina propria single cell suspension from the remaining tissue, $4 \mathrm{ml}$ of $1 \times$ Liberase TM ( 0.2 Wunsch unit $/ \mathrm{ml}$, Millipore Sigma) $+200 \mathrm{~K} / \mathrm{ml}$ DNase I (Millipore Sigma) in Solution 3 was added and sample was incubated at $37^{\circ} \mathrm{C}$ for $15 \mathrm{~min}$, with $200 \mathrm{rpm}$ shaking. Following digestion, $2 \mathrm{ml}$ of cRPMI was added and then samples were triturated 3 times through an 18-gauge needle and then samples were filtered through a $70 \mu \mathrm{m}$ sieve. The filtrate was combined with the epithelial cells from above and centrifuged at $300 \times g$ for $5 \mathrm{~min}, 4{ }^{\circ} \mathrm{C}$. Cells were then stained for flow cytometry analysis.

\section{Flow cytometry}

Epithelial and lamina propria lymphocyte cells were stained with the viability Zombie Aqua dye from Biolegend (San Diego, CA) per manufacturer's protocol. Then cells were pretreated with TruStain fcX (Biolegend) in order to block non-specific binding of antibodies to Fc receptors. Mouse CD1d- $\alpha$ GalCer tetramers (PBS57; NIH Tetramer Core Facility) conjugated to Brilliant Violet 421 (BV421) were utilized to identify iNKT cells (TCR $\beta^{+}$ CD1dtet ${ }^{+}$). All of the following mouse antibodies were purchased from Biolegend except if noted differently. The following mouse antibodies were used to stain for Tregs, Th17, and iNKTh17 cells: anti-TCR $\beta$ (H57-597), anti-CD4 (GK1.5). The following mouse antibodies were used to stain for DCs: anti-CD45 (30-F11), anti-CD11b (M1/70), anti-I-A/I-E (M5/114.15.2), anti-CD103 (2E7), anti-CD11c (N418). The following antibodies were used to stain for IECs: anti-EpCam (G8.8) and anti-CD284 (TLR4; SA15-21). The following antibodies were utilized to stain for B10 cells: anti-CD1d (CD1.1; 1B1), anti-CD5 (53-7.3), anti-B220/CD45R (RA3-6B2), and anti-CD19 (1D3/CD19). For intracellular/intranuclear staining, the Foxp3/Transcription Factor Staining Set (eBioscience) was utilized when staining for anti-IL-17F (9D3.1C8), anti-IL-17A (TC11-18H10.1), anti-Foxp3 (150D) antiTNFa (MP6-XT22), anti-IL-22 (Poly5164), anti-IL-10 (JES5-16E3), and anti-ZO-1 (R26.4C, eBioscience, San Diego, CA). Samples were acquired on an BD LSRII or BD FACSymphony (BD, San Jose, CA) and analyzed with FlowJo software (BD).

\section{$16 \mathrm{~S}$ metagenomic sequencing library preparation}

DNA was isolated from intestinal fecal content from each of the different regions using the QIAamp DNA Stool Isolation kit and Qiacube from Qiagen per manufacturer's recommended protocol. A $16 \mathrm{~S}$ rRNA library was prepared as follows. The PCR reaction contained microbial genomic DNA (5 ng/ $\mu$ l in $10 \mathrm{mM}$ Tris, $\mathrm{pH} 8.5$ ), $1 \mu \mathrm{M}$ 16S Amplicon Forward primer (5'-TCG TCG GCA GCG TCA GAT GTG TAT AAG AGA CAG CCT ACG GGN GGC WGC AG-3'), $1 \mu \mathrm{M}$ 16S Amplicon Reverse primer (5'-GTC TCG TGG GCT CGG AGA TGT GTA TAA GAG ACA GGA CTA CHV GGG TAT CTA ATC C-3'), $2 \times$ KAPA HiFi HotStart ReadyMix (Roche Kapa Biosystems, Wilmington, MA). PCR program parameters were initial denaturation at $95^{\circ} \mathrm{C}$ for $3 \mathrm{~min}, 25$ cycles of $95^{\circ} \mathrm{C}$ for $30 \mathrm{~s}, 55^{\circ} \mathrm{C}$ for $30 \mathrm{~s}$, and $72{ }^{\circ} \mathrm{C}$ for $30 \mathrm{~s}$ and then a final extension of $72{ }^{\circ} \mathrm{C}$ for $5 \mathrm{~min}$. Next, the Index PCR was prepared using the Nextera XT Index Kit, PCR Cleanup, and Illumina MiSeq sequencing was performed following manufacturer's protocol (Illumina, San Diego, CA). Samples were processed plug-ins provided in the qiime2 [7] pipeline. Briefly, paired end reads were joined using vsearch [39], then quality-filtered with a minimum PHRED-score of 4 . The joined reads were denoised using deblur [3], producing a feature table of amplicon sequence variants (ASVs). Next, the ASVs were assigned to taxonomy using a naïve bayes classifier [6]. The classifier was trained on the sequenced region of the 16-S gene (V3-V4), using SILVA [6] v128, 99\% OTU sequences. ASVs were aligned using MAFFT [21], then using only phylogenetically informative positions, an unrooted tree was constructed using FAST Tree [36]. The unrooted tree and ASV feature table were imported in R and the package phyloseq [29] was used to first collapse the feature table to level of species, then calculate multiple alpha diversity metrics (Observed Richness, Simpson's diversity index, Shannon's diversity index) and beta diversity metrics (Jaccard distance, Bray-curtis distance, unweighted Unifrac distance and weighted Unifrac distance). PCoA plots were then generated from the beta diversity metrics. Differential abundance of taxa was assessed using $R$ package DESeq2 [26]. Taxa were considered to be differentially abundant at an FDR of 0.05 . The metagenomics for the microbiome sequencing was uploaded to Bioproject with accession number PRJNA700677.

\section{Statistics}

Flow cytometry analyses and microbiome indexes were assessed by 2-way ANOVA with Uncorrected Fisher's LSD. The correlation graphs of immune cell parameters to microbiome phyla abundances were performed and Pearson $r$ values (Additional files 9, 10: Tables S1, S2) were calculated in Graph Pad Prism version 9.1.0.

\section{Results}

\section{IEC TLR4 expression decreases after anastomosis}

From two murine surgical models, Roux-en-Y and endto-end anastomoses (Fig. 1), we examined the TLR4 
expression of $\mathrm{EpCam}^{+} \mathrm{ZO}-1^{+}$IECs by flow cytometry. We observed that the numbers of $\mathrm{EpCam}^{+} \mathrm{ZO}-1^{+}$ TLR4 ${ }^{+}$IECs were decreased significantly after Rouxen-Y and end-to-end anastomoses within the B segment and in the $\mathrm{C}$ segment of end-to-end anastomosis in comparison to the respective no surgery control (Fig. 2).

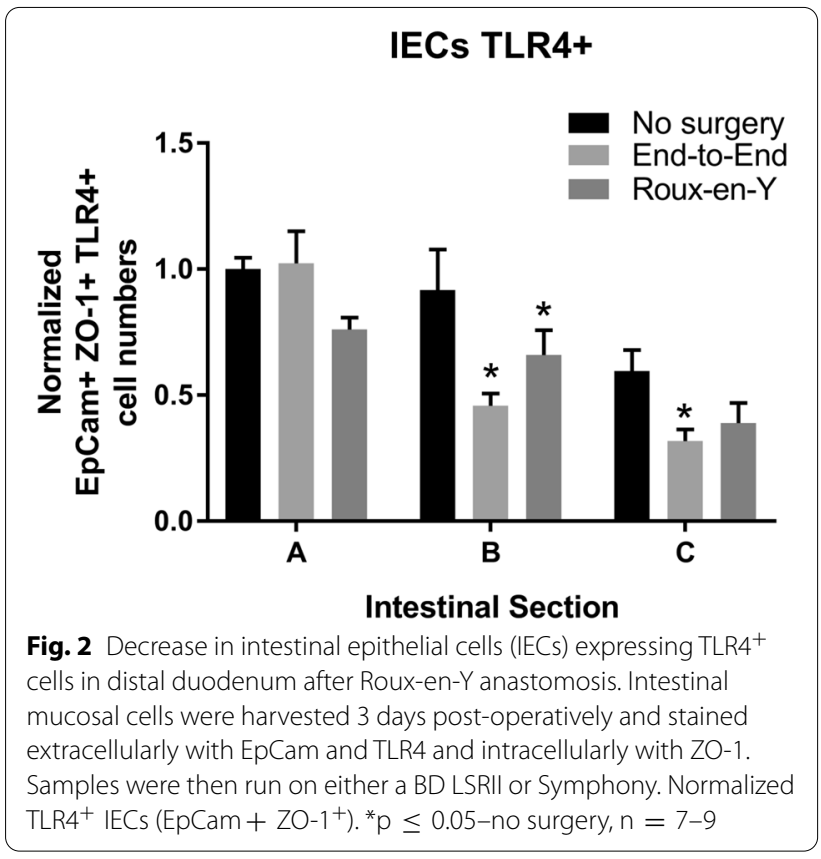

\section{Microbial population shifts after anastomosis}

The alpha diversity microbiome analyses showed a significant decrease in Observed, Shannon, and Evenness indices for all intestinal segments in the Roux-en-Y compared to the no surgery control (Fig. 3). Also, Roux-en-Y segment A was significantly different to the end-to-end anastomosis segment $\mathrm{A}$ in the Observed indices. The $\mathrm{B}$ and $C$ segments after end-to-end anastomosis were only significant to no surgery control in the Shannon and Evenness indices (Fig. 3). When the relative abundances were evaluated, there was a noticeable decrease in major phyla Firmicutes, Bacteroidetes, and Saccharibacteria and an increase in Proteobacteria in both of the end-to-end and Roux-en-Y anastomosis surgery groups compared to no surgery control (Fig. 4). There were also significant changes seen in the bacteria order and class between the surgery groups and no surgery control (Additional file 1: Figure S1). Specifically, Bacteroidia, Clostridia, and Deltaproteobacteria class decreased, while Gammaproteobacteria class increased in abundance for the surgery groups (Additional file 1: Figure S1A). Bacteroidales, Clostridiales, and Desulfovibrionales order decreased, while Enterobacteriales order increased in abundance for the surgery groups (Additional file 1: Figure S1B).

\section{Th17, iNKTh17, iNKT IL-10+, and Treg cells increase after anastomosis}

After both Roux-en-Y and end-to-end anastomoses, we observed that the expression of TCR $\beta$ increased for both $T$ cells and iNKT cells (Figs. 5A, 6A) in segments A and B. This increased TCR $\beta^{\text {hi }} \mathrm{CD} 4^{+} \mathrm{T}$ cell population (Fig. $5 \mathrm{~B}$ )

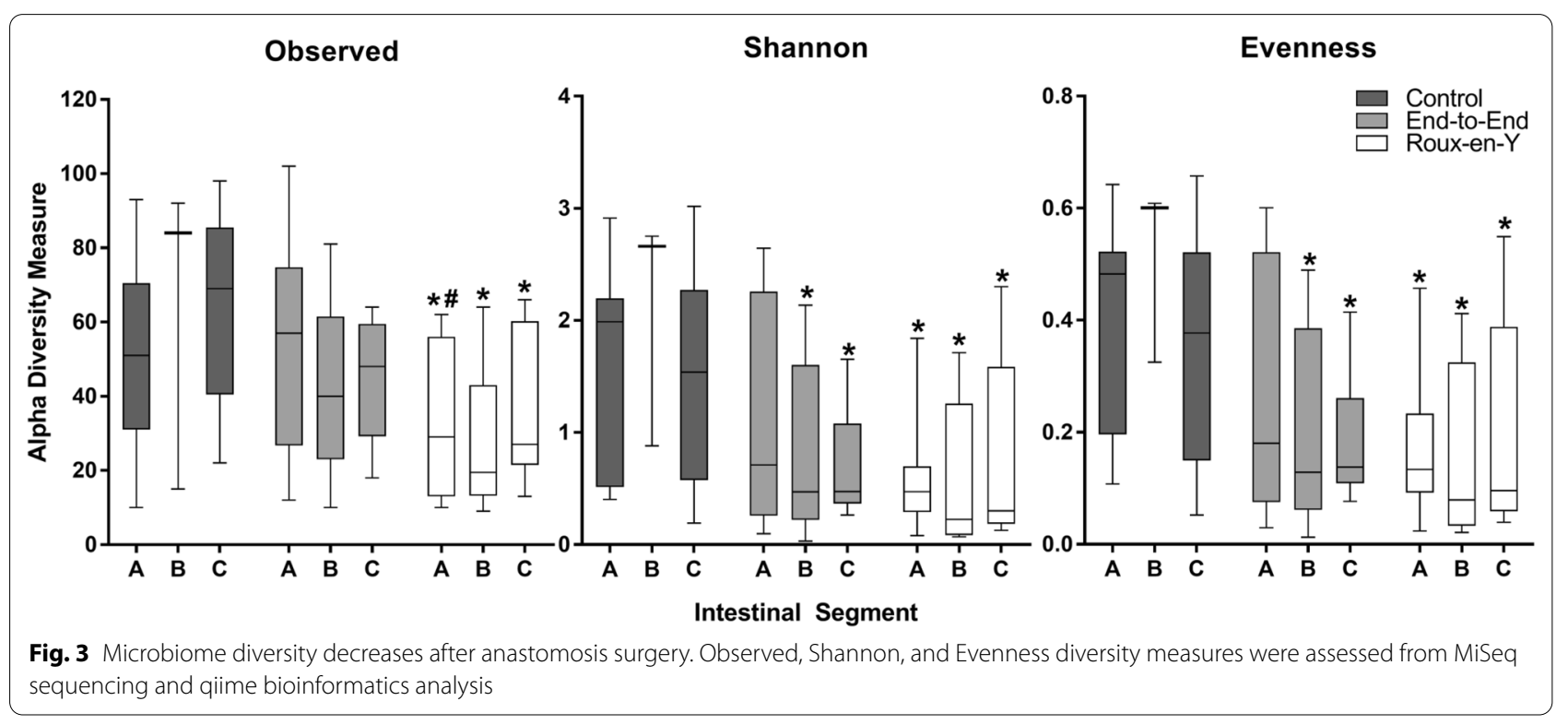



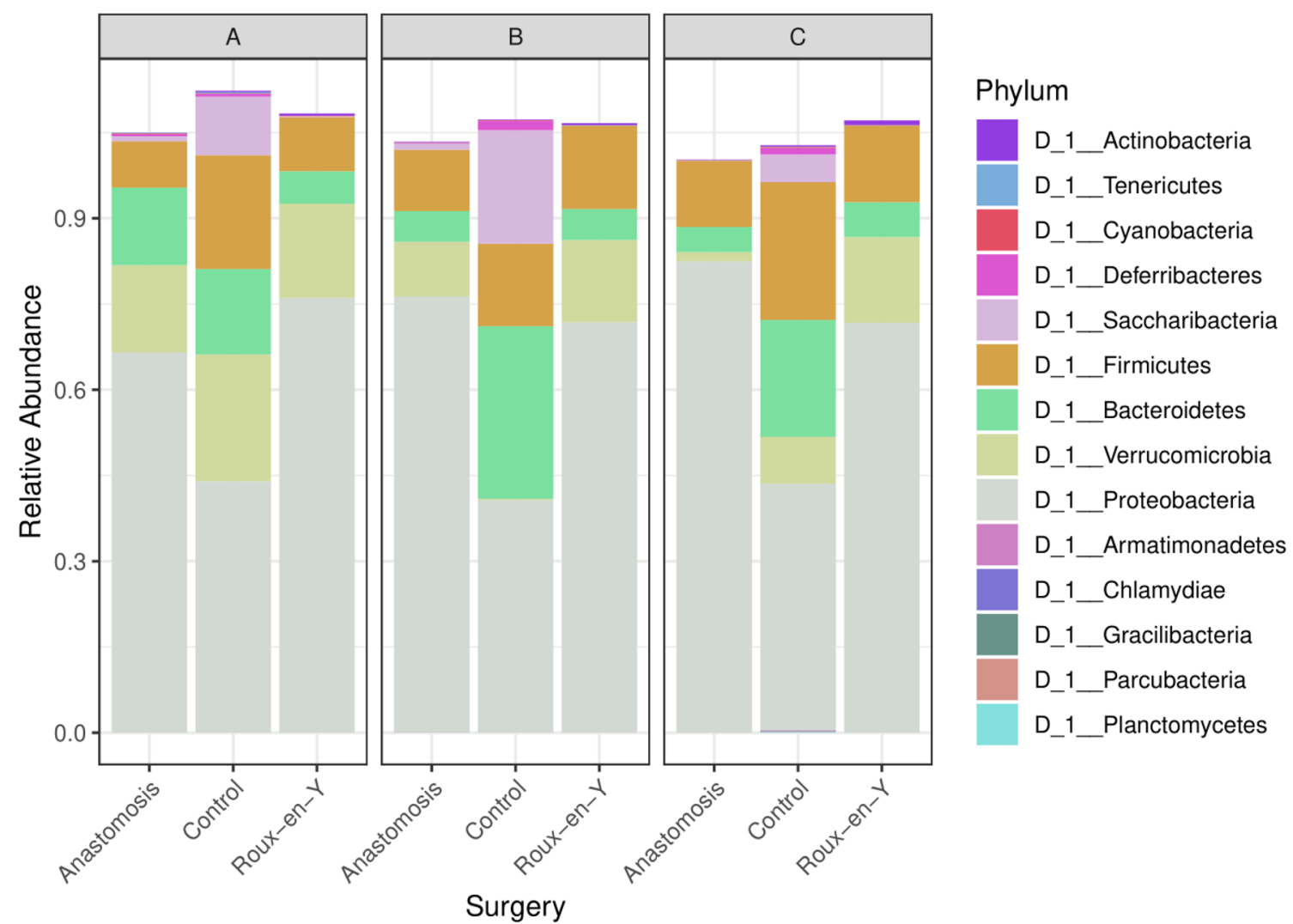

Fig. 4 Relative abundance of Firmicutes and Bacteroidetes phylums decreased while Proteobacteria phylum increased after either anastomotic surgeries. Relative abundance composition of the intestinal microbiome phylum for each intestinal segment (top heading) within each surgery group (x-axis label)

were IL-17A ${ }^{+}$IL- $17 \mathrm{~F}^{+}$indicating an increase in Th17 cells (Fig. 5C). Of the TCR $\beta^{\text {hi }}$ Th17 cell population, there was a significant increase in TNF $\alpha^{+}$Th17 cells after Roux-en-Y anastomosis in segments A and B (Fig. 5D). Both anastomoses had an increase in IL-22 ${ }^{+}$TCR $\beta^{\text {hi }}$ Th17 cells in segments A and B (Fig. 5E). iNKT cell numbers increased in anastomosis segments A and B and were TCR $\beta^{\text {hi }}$ (Fig. 6B). A significantly large percentage of iNKT cells had an increase in $\mathrm{IL}-10^{+}$expression (Additional file 2: Figure S2A, Fig. 6C). Additionally, we observed a 13\% increase in iNKT cells that were expressing IL-22 $2^{+}$(Additional file 2: Figure S2B), suggesting an iNKTh17 subset. Therefore, we further gated the iNKT cells with IL-17A/F and indeed we observed a trending increase in iNKTh17 and iNKTh17 IL-22 ${ }^{+}$cells with significance reached in the end-to-end segment $A$ and Roux-en-Y segment $B$ in comparison to the respective no surgery controls (Fig. 6D, E). Alternatively, the Treg population was TCR $\beta^{+}$but was not high in TCR $\beta$ (Additional file 3: Figure S3). The Treg cells were increased after both anastomoses surgeries with significance seen most greatly in segment A (Fig. 7A). These Treg cells were also significantly expressing IL- $10^{+}$and $\mathrm{IL}-22^{+}$in segment A (Fig. 7B, C; Additional file 4: Figure S3).

\section{A novel CD11 $b^{\text {hi }} C D 103^{\text {mid }} D C$ population emerges after anastomosis}

We observed a decreased shift in $\mathrm{CD} 11 \mathrm{~b}^{+} \mathrm{CD} 103^{+} \mathrm{DCs}$ to a new population subset of $\mathrm{CD} 11 \mathrm{~b}^{\text {hi }} \mathrm{CD} 103^{\text {mid }} \mathrm{DC}$ population after end-to-end and Roux-en-Y anastomoses (Fig. 8A, B, C). This new subset of DCs had an increase

\footnotetext{
(See figure on next page.)

Fig. 5 Increase in TCR $\beta^{\text {hi }}$ Th17 cells after end-to-end and Roux-en-Y anastomosis surgery. Intestinal mucosal cells were harvested 3 days post-operatively and stained extracellularly with TCR 3 and CD4 and intracellularly with IL-17A, IL-17F, IL-22, and TNFa. Samples were then run on either a BD LSRII or Symphony. A Dot plots showing increased TCR $\beta$ expression after both anastomotic procedures from surgical segments A, B, and

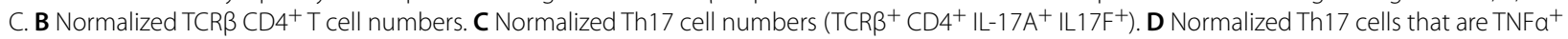
or $\mathbf{E} \| L-22^{+} .{ }^{*} \mathrm{p} \leq 0.05-$ no surgery, $\mathrm{n}=5-7$
} 
(a)

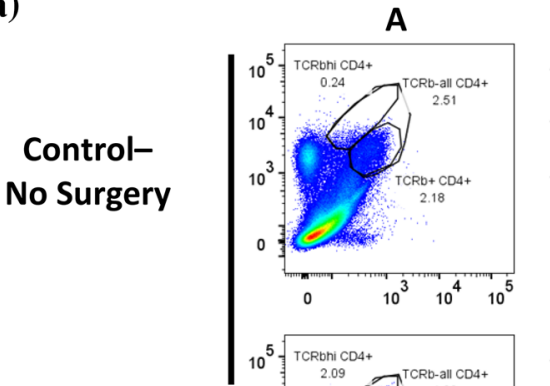

End-to-End
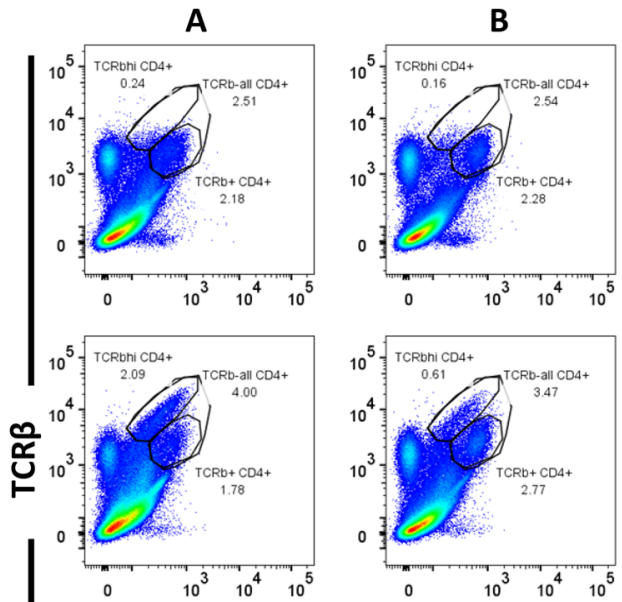

Roux-en-Y
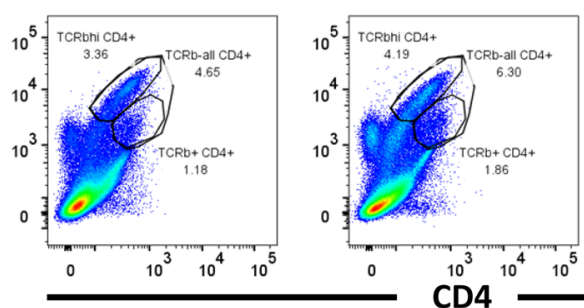
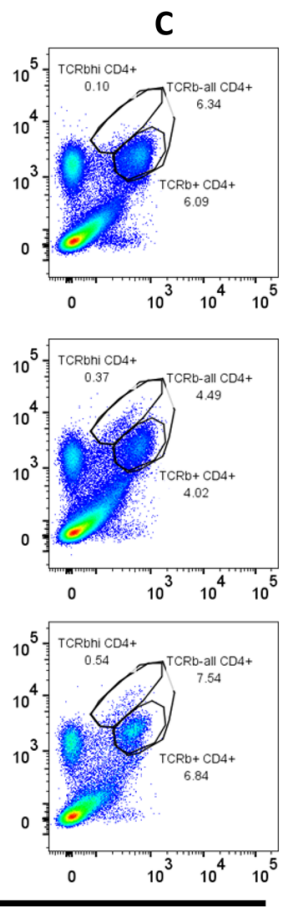

(b)

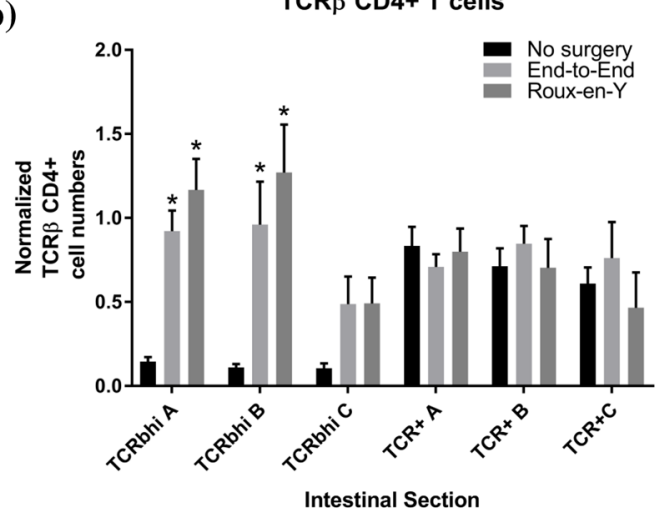

(d)

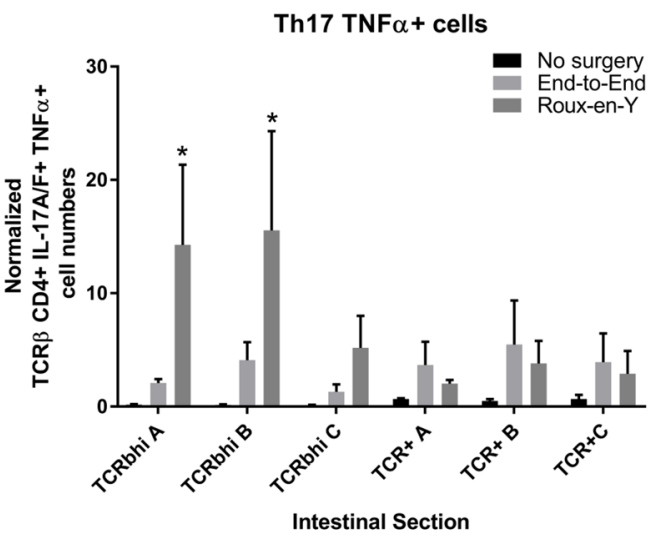

(c)

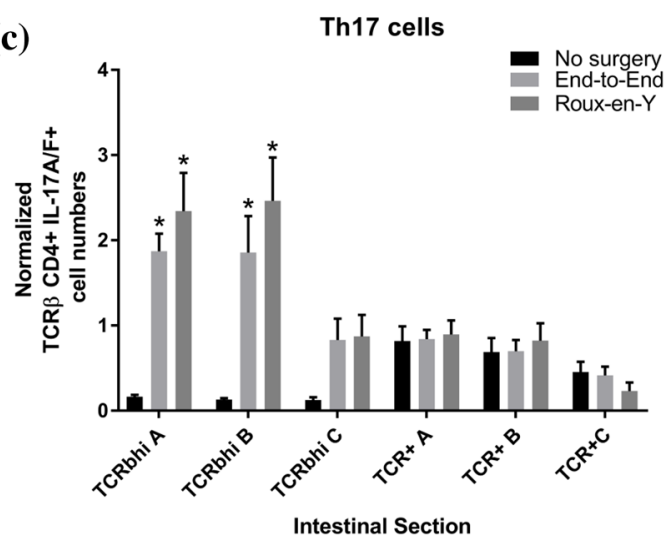

(e)

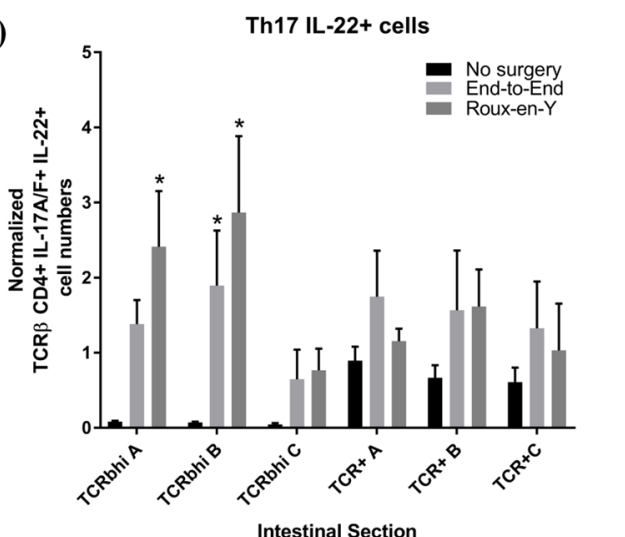

Fig. 5 (See legend on previous page.) 
in the expression of IL-10 in all three segments, while the $\mathrm{CD}_{11 b^{+}} \mathrm{CD} 103^{+}$populations had a trending decrease (Fig. 8D). TGF $\beta$ expression in DC subsets were also evaluated but there were no significant differences between the intestinal segments or between the control and surgery groups, although there was a trending increase (Fig. 8E).

\section{Direct correlations between microbiome phlya and immune cell populations}

When the major phyla Firmicutes, Bacteroidetes, and Proteobacteria were correlated to immune cell populations iNKT IL- $22^{+}$, iNKT IL- $10^{+}$, DC CD $11 b^{\text {hi }}$ CD $103^{\text {mid }}$, Th17 IL-22 ${ }^{+}$, and Tregs. There were consistent, correlative shifts that were observed in comparison to the control. The correlation graphs reveal the direct association of increases in iNKTs, DCs, Th17, and Treg cells to decreases in Firmicutes and Bacteroidetes and an increase in Proteobacteria within the end-to-end and Roux-en-Y surgery groups (Fig. 9, Additional files 5, 6: Figures S4, S5). Additionally, when only the surgical segments were assessed, we observed that the change in bacteria phyla were consistent across all surgery segments with the highest numbers of iNKTs, DCs, Th17 and Treg cells being in segment $\mathrm{A}$ and decreased as we moved distally to the segment $C$ (Fig. 10, Additional files 7, 8: Figures S6, S7). Overall, there was a correlative significance observed in iNKT IL-10 vs. Firmicutes in segments B and C (Fig. 10, Additional file 9: Table S1) and the end-to-end anastomosis had correlative significance in the iNKT IL-10 vs. Firmicutes and the Th17 vs. Firmicutes correlations (Fig. 9, Additional file 10: Table S2). The Treg cells had a correlative significance to Bacteroidetes and Proteobacteria in segment A and to Firmicutes in segment C (Fig. 10, Additional file 9: Table S1).

\section{Discussion}

This current study further identifies the immune cell and microbiome shifts that occur after small intestinal anastomosis, in comparison to the homeostatic nonsurgical control. We did not perform a sham-operated control as we felt the non-surgical control offered a better perspective on the presurgical normal microbiome and immune cell population environment to make comparisons to, however, we do recognize that a sham-operated control could have added more rigor to these studies, and we will consider doing them in our future work. Overall, we observed a decrease in microbiome diversity which included decreases in the major phyla Firmicutes, Bacteroidetes, and Saccharibacteria but then an increase in Proteobacteria after anastomosis. We found that there were increases in Th17 and iNKTh17 cell populations and that these Th17 and iNKTh17 cells had a higher expression of TCR $\beta$, while the increased Treg populations had homeostatic expression levels of TCR $\beta$. Additionally, these Treg populations also had an increase in IL-10 and IL-22, which are necessary for mucosal wounding healing [25]. Evaluating the DC populations after anastomosis revealed an increase in a subpopulation that was $\mathrm{CD}_{11} \mathrm{~b}^{\text {hi }} \mathrm{CD} 103^{\mathrm{mid}}$, while the conventional $\mathrm{CD} 11 \mathrm{~b}^{+}$ $\mathrm{CD}_{103}{ }^{+}$DCs decreased. The CD11b ${ }^{\text {hi }}$ CD $103^{\text {mid }}$ DCs were expressing IL-10. The increases in iNKTs, DCs, Th17, and Treg cells correlated to decreases in Firmicutes and Bacteroidetes phyla and an increase in the Proteobacteria phylum within the end-to-end and Roux-en-Y anastomoses surgery groups.

Studies involving germ-free mice have demonstrated that there is an impaired rate of intestinal epithelial cell migration, indicating the necessity of commensal bacteria for effective migration during wound healing [2]. The pattern-recognition receptor, TLR4 specifically detects the conserved molecular product lipopolysaccharide (LPS) on microorganisms [37]. The key functions of the TLR family are to act as sensors of microbial infection, initiate inflammatory and immune responses, and to aid in mucosal epithelial healing and homeostasis [37]. We specifically observed that the expression of TLR4 decreased after anastomotic surgery (Fig. 2). Interestingly, if there is not proper activation of TLRs on epithelial cells, there will be abnormalities in the intestinal epithelial homeostasis and production of cytokines and heat-shock proteins. If there is a defect in the assembly and release of these factors after intestinal injury, the detection and protection of commensals is impeded [37]. Therefore, this leads to a dysregulated interaction between commensals and TLRs resulting in chronic inflammation and tissue damage. So, a critical balance between the activation of TLRs by commensals and the protective action induced by TLRs will impact whether proper homeostasis can be maintained, or mucosal injury (including by surgery) can be properly healed. How TLR involvement and inflammation affect the microbiome

(See figure on next page.)

Fig. 6 Increase in iNKT cells expressing IL-10 and IL-22 after end-to-end and Roux-en-Y anastomoses. Intestinal mucosal cells were harvested 3 days post-operatively and stained extracellularly with TCR $\beta$ and CD1dtet and intracellularly with IL-10, IL-22, IL-17A, and IL-17F. Samples were then run on either a BD LSRII or Symphony. A, B Significant increase in normalized iNKT (TCR ${ }^{+}$CD1 dtet ${ }^{+}$) cell numbers in distal duodenum. $\mathbf{C}$ Normalized cell numbers showing increased IL-10 + expression in iNKT cells after both anastomotic surgeries. D Normalized iNKT cells that are IL-17A ${ }^{+}$and IL-17F+ and then $\mathbf{E}$ iNKTh17 cells were gated for IL-22 ${ }^{+}$cells. ${ }^{*} \mathrm{p} \leq 0.05-$ no surgery, $\mathrm{n}=5-8$, except IL-10 and IL 17A/F, $\mathrm{n}=8-10$ 


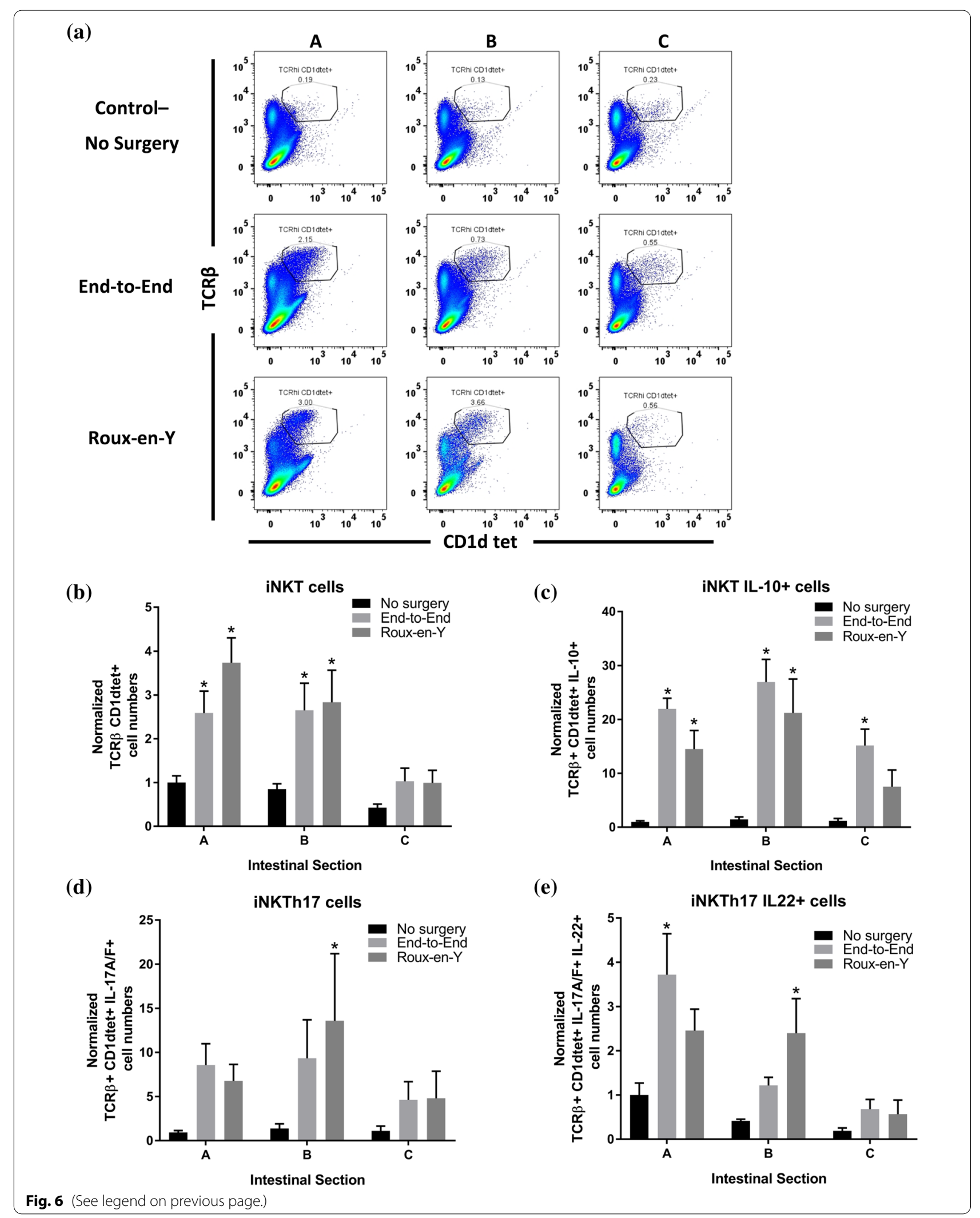



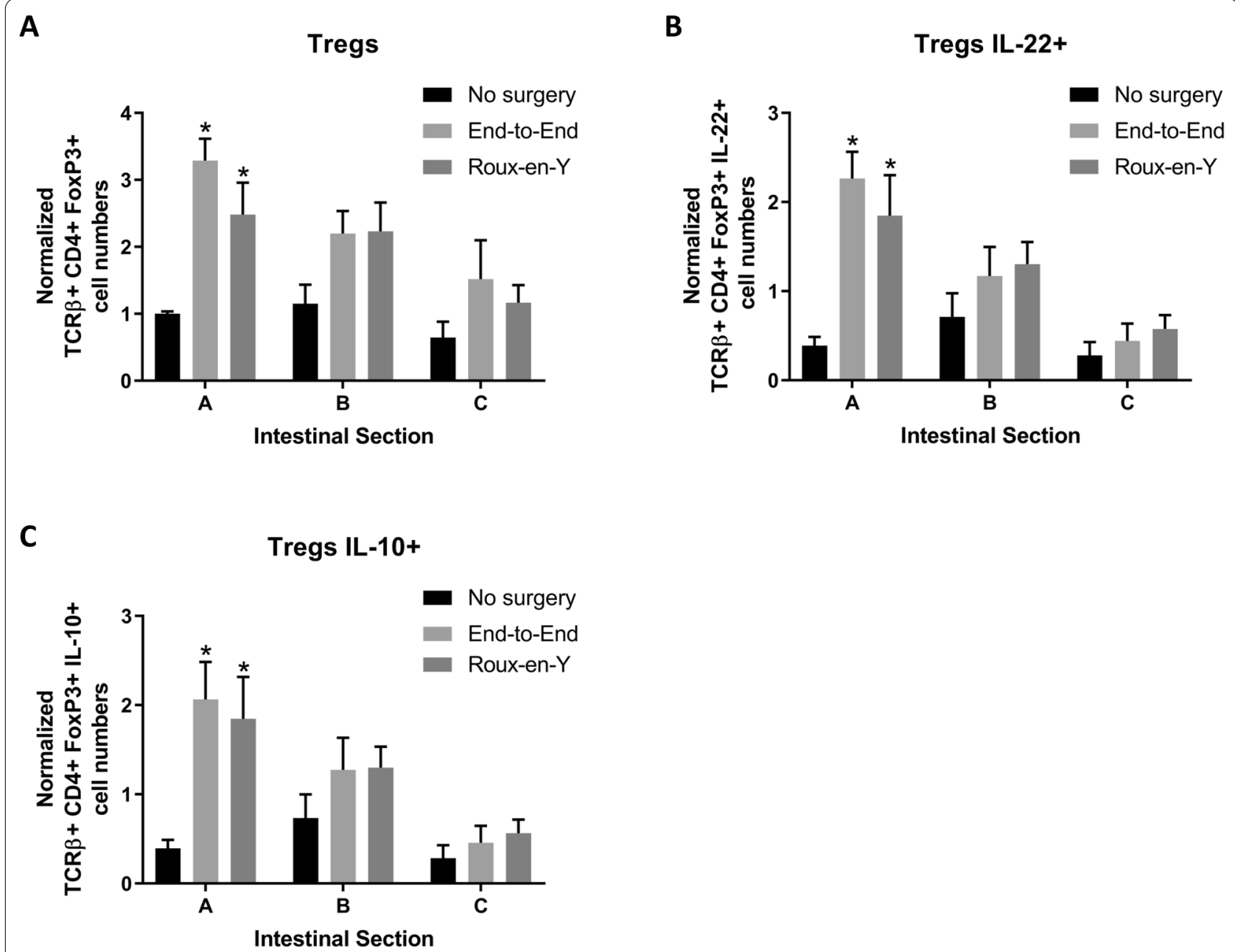

Fig. 7 Increase in Treg cells expressing IL-10 and IL-22 after end-to-end and Roux-en-Y anastomoses. Intestinal mucosal cells were harvested 3 days post-operatively and stained extracellularly with TCR $\beta$ and CD4 and intracellularly with FoxP3, IL-10, and IL-22. Samples were then run on either a BD LSRIl or Symphony. A Significant increase in normalized Treg $\left(\mathrm{TCR} \beta^{+} \mathrm{CD} 4^{+}\right)$cell numbers and Treg cells that are $\mathbf{B} \| \mathrm{L}-22^{+}$or $\mathbf{C} \| \mathrm{L}-10^{+}$. ${ }^{*} \mathrm{p} \leq 0.05-\mathrm{no}$ surgery, $n=6,7$

environment could be further explored by comparing the effects of intraperitoneal administration of TLR4 agonist LPS from Escherichia coli versus administration of TLR4 antagonist LPS from cyanobacteria Rhodobacter sphaeroides after anastomotic surgery [51]. However, this exceeds the scope of the current study.

IBD patients are associated with a lower abundance of Firmicutes and higher abundance of Proteobacteria and Bacteroidetes [2, 28]. Mice that have undergone ileocecal resection (ICR) plus a single antibiotic injection at surgery, have decreased phylogenetic diversity by 7 days post-operative. Prior to ICR, Firmicutes and Bacteroidetes were the predominant strains in the jejunum, but then only Firmicutes remained the dominant population 28 days after ICR, whereas Bacteroidetes was $0.01 \%$ of abundance and there was an increase in Proteobacteria [12]. Another study conducted 75\% small bowel resection (SBR) in piglets and showed an increase in Firmicutes and a decrease in Bacteroidetes and Proteobacteria 2 and 6 weeks post-operative [23]. Another study performed $50 \%$ proximal SBR in mice and found that there was little to no difference in microbiota diversity between the SBR mice and sham mice that had a transection and anastomosis 7 days post-operative [48]. They did not however compare the sham mice to non-operated mice. In our anastomotic study, we observed significant decrease in microbiome diversity and in major phyla Firmicutes, Bacteroidetes, and Saccharibacteria but an increase in Proteobacteria in both of the end-to-end and Roux-en-Y anastomosis surgery groups compared to non-operative 
(a)

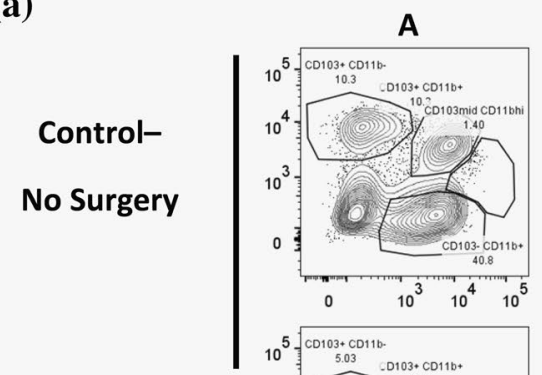

End-to-End

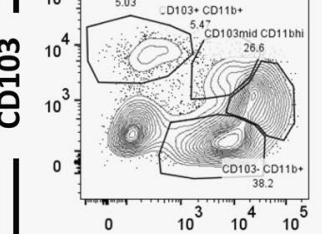

Roux-en-Y

(b)

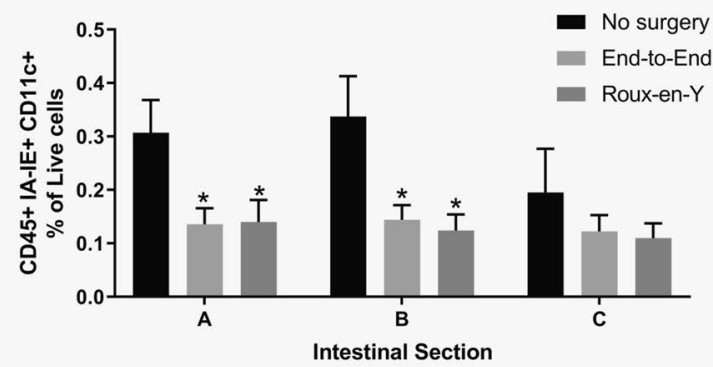

(d)

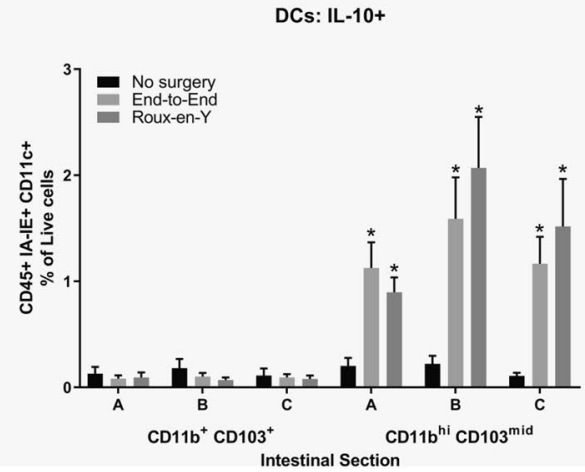

B
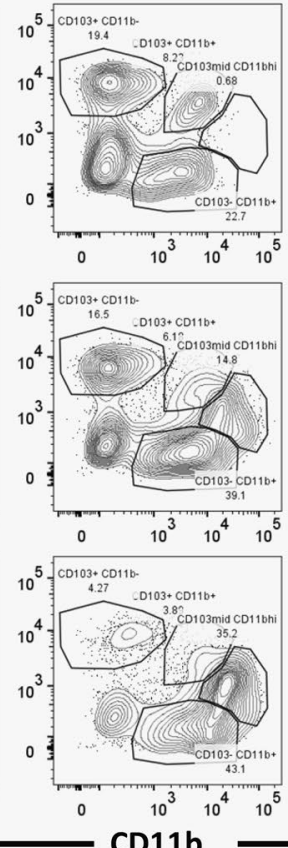

CD11b
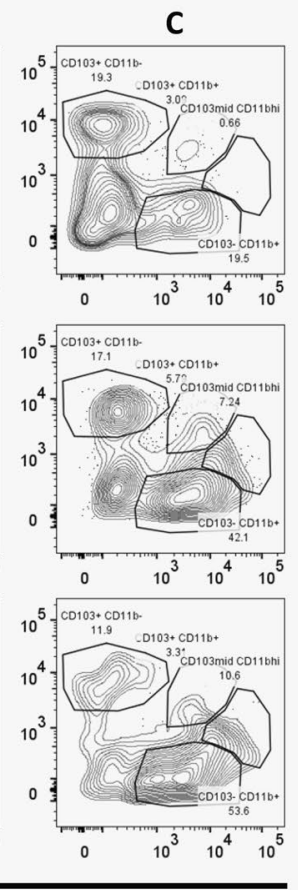

(c)

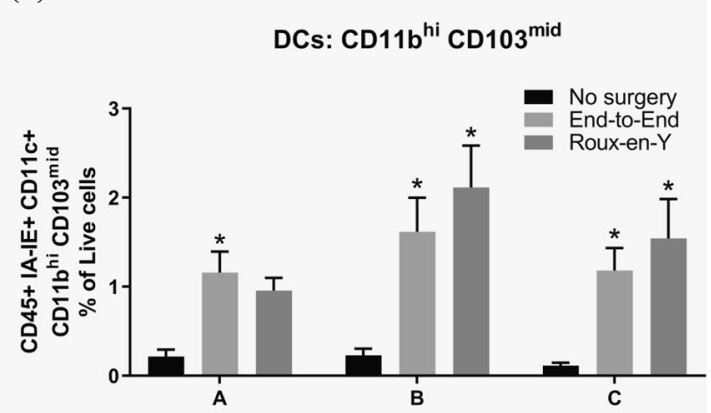

Intestinal Section

(e)

$$
\text { DCs: CD11b }{ }^{\text {hi }} \text { CD103 }{ }^{\text {mid }} \text { TGF }^{+}
$$

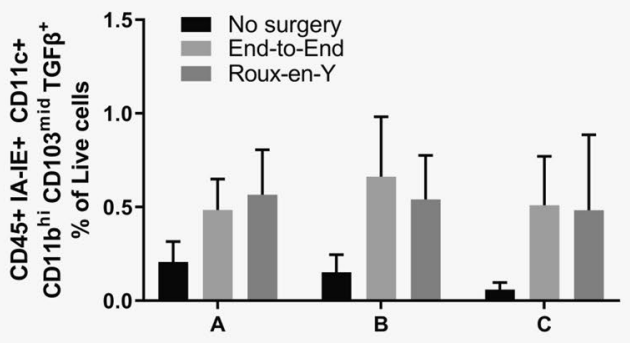

Intestinal Section

Fig. 8 A new population of $C D 11 b^{\text {hi }} C D 103^{\text {mid }}$ DCs emerges after both end-to-end and Roux-en-Y anastomosis and are expressing IL-10. Intestinal mucosal cells were harvested 3 days post-operatively and stained extracellularly with CD45, IA-IE, CD1 10, CD11 b, and CD103 and intracellularly with IL-10. Samples were then run on either a BD LSRII or Symphony. A Dot plot representation and $\mathbf{B} \%$ of live cell numbers of CD $11 b^{+}$CD $103^{+}$and $\mathbf{C}$ $\mathrm{CD} 11 \mathrm{~b}^{\text {hi }} \mathrm{CD} 103^{\text {mid }} \mathrm{DC}\left(\mathrm{CD} 45^{+} \mid \mathrm{A}-\mathrm{IE}^{+} \mathrm{CD} 110^{+}\right)$populations. D Expression of $\mathrm{LL}-10 \mathrm{in} \mathrm{CD} 11 \mathrm{~b}$ CD103 DC populations. $\mathbf{E}$ Percent of live cell numbers of CD $11 b^{\text {hi }} C^{2} 103^{\text {mid }}$ DCs that are TGF $\beta^{+*} p \leq 0.05-$ no surgery, $n=6-9$ 
A

iNKT IL-22 vs. Firmicutes

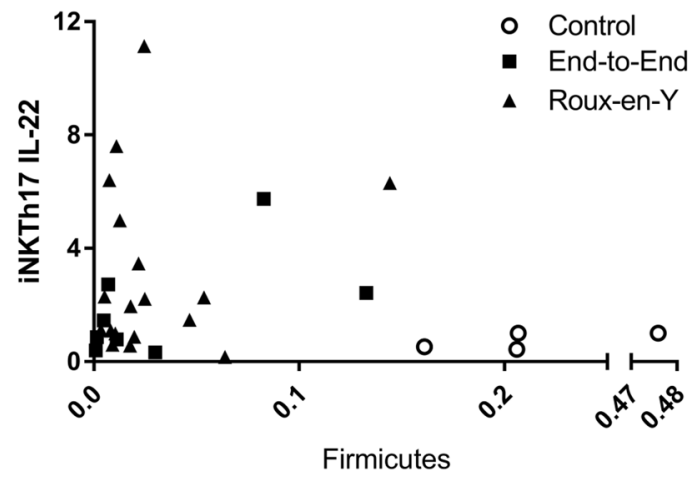

C

DCs vs. Firmicutes

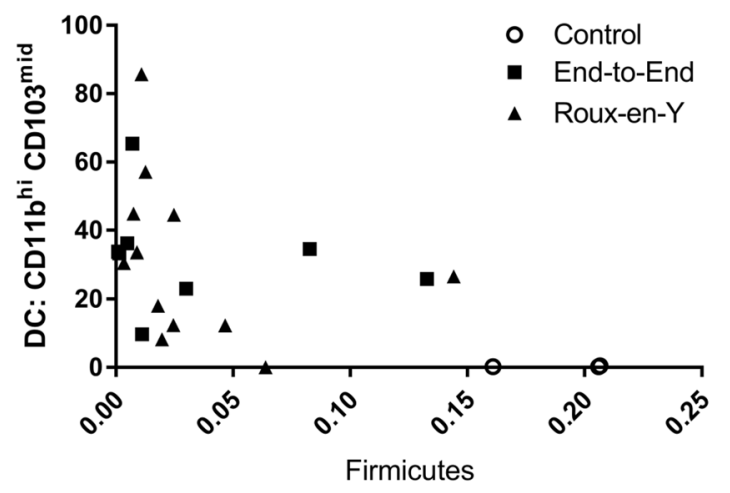

$\mathbf{E}$

Treg vs. Firmicutes

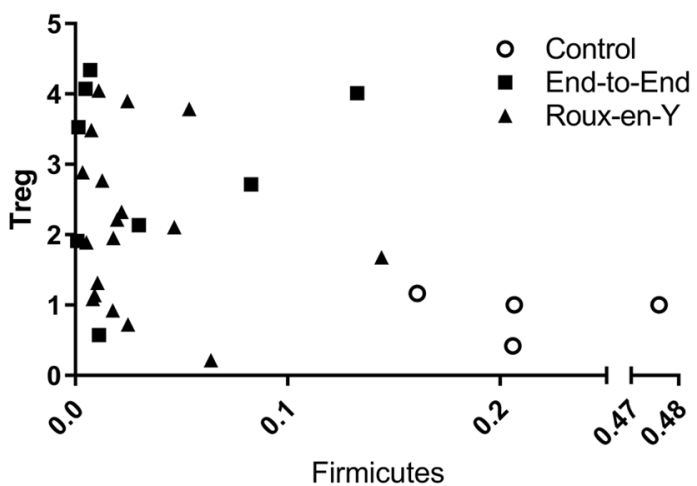

B

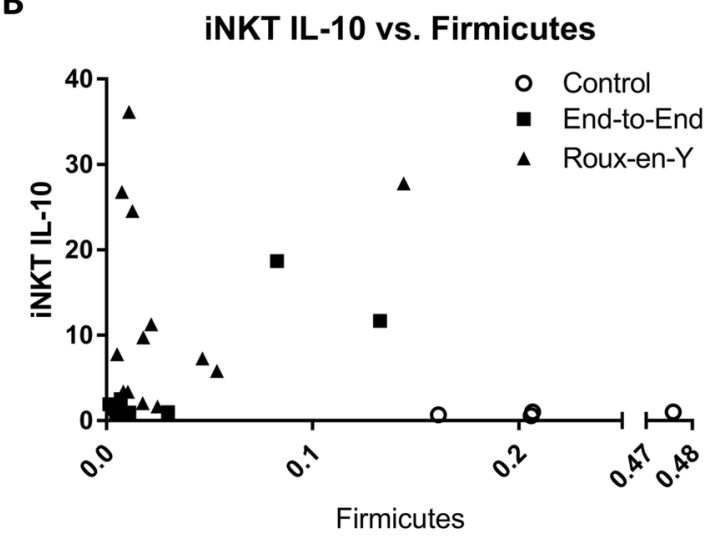

D

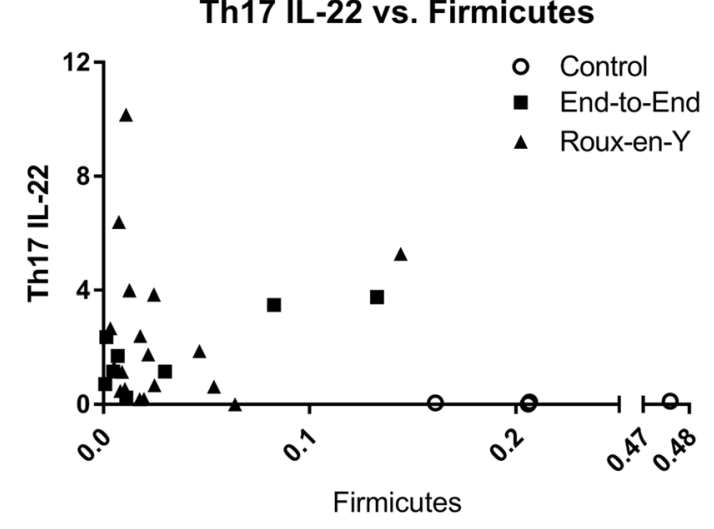

Fig. 9 Immune cell populations correlate to Firmicutes with distinct patterns based on surgical segments. Correlation graphs of $\mathbf{A}$ iNKT (TCR ${ }^{+}$

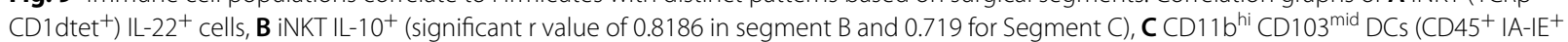

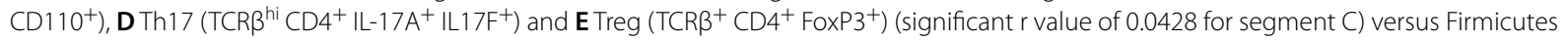
within surgical segments. Pearson correlation coefficient ( $r$ ) are found in Additional file 9: Table S1

control. The differences we observed in the microbiome diversity in comparison to the forementioned studies could be due to timing of post-operative fecal collection (our study collected at day 3 vs. others at days 7, 14, and 42), type of surgery performed, and the species. Therefore, our study evaluates an acute time period that is 
A

iNKT IL-22 vs. Firmicutes

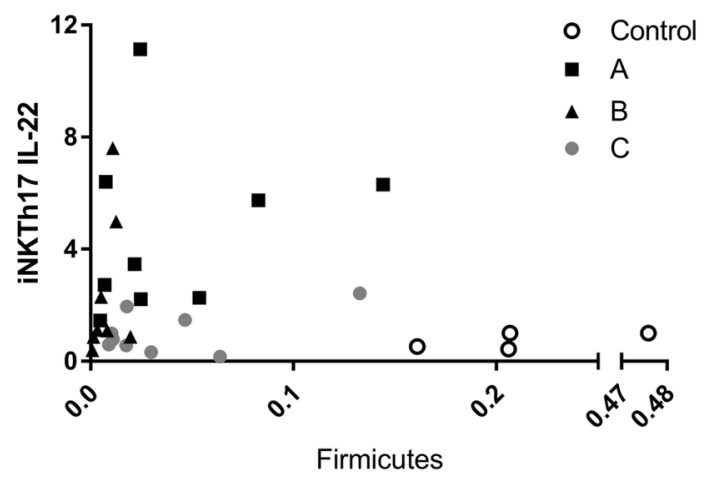

C

DCs vs. Firmicutes

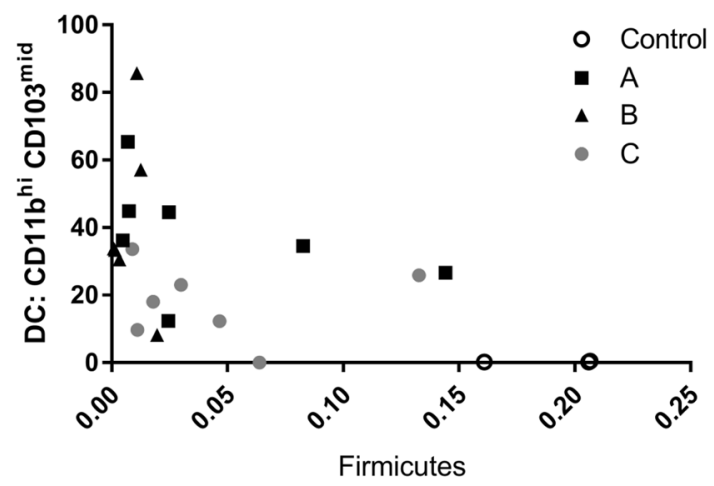

E

Treg vs. Firmicutes

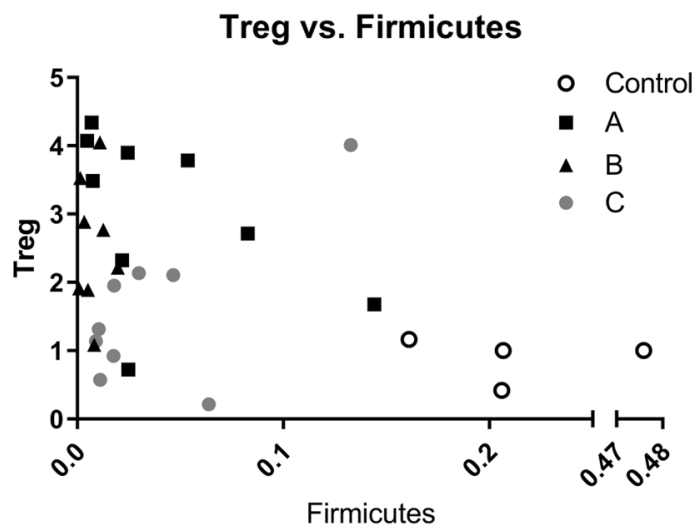

B

iNKT IL-10 vs. Firmicutes

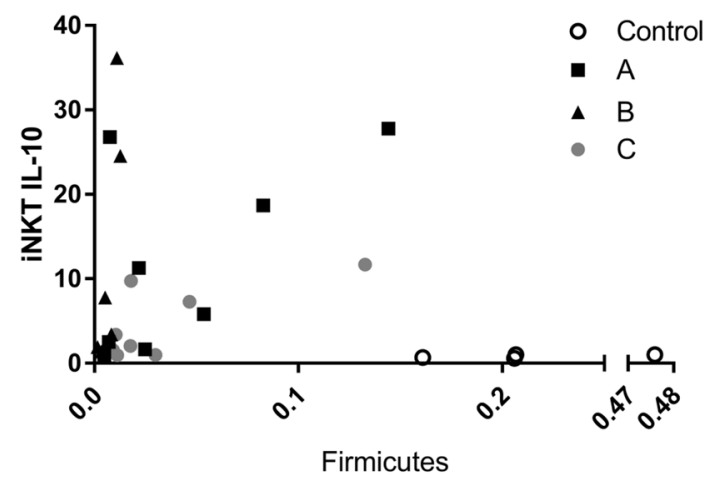

D

Th17 IL-22 vs. Firmicutes

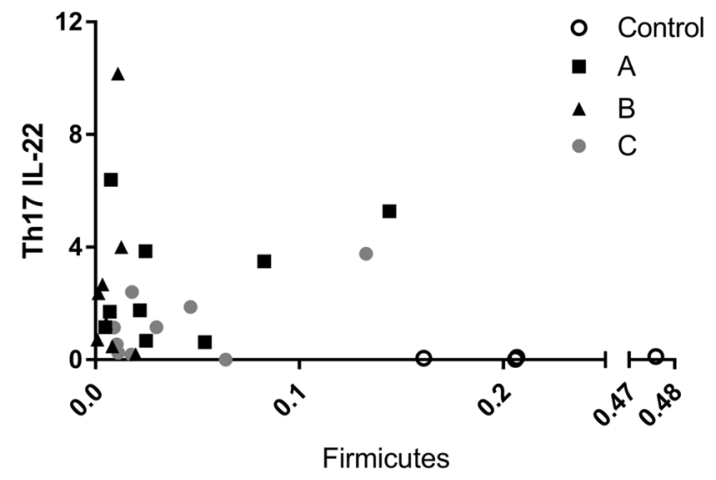

Fig. 10 Immune cell populations correlate to Firmicutes with distinct patterns based on either anastomotic surgery. Correlation graphs of $\mathbf{A}$ iNKT

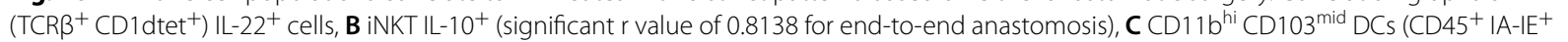

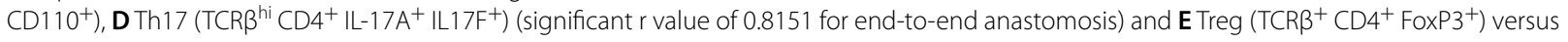
Firmicutes within surgery type. Pearson correlation coefficient ( $r$ ) are found in Additional file 10: Table $\mathbf{S 2}$

necessary for the establishment of proper healing or by which the timing when most anastomoses start to fail [43]. Moreover, we correlated these diversity changes to the response of the immune cells at day 3 . We correlated the decrease in Firmicutes after anastomosis surgery to an increase in Th17 IL-22 $2^{+}$cells, with the greatest increases seen in the proximal segments $\mathrm{A}$ and $\mathrm{B}$ and a less of an increase in the distal segment $\mathrm{C}$ ileal region 
(Fig. 10D). This contrasts to how segmented filamentous bacteria from the Firmicutes phylum, are able to bind to the epithelial surface of the ileum and penetrate the mucus layer [25]. They then can induce the differentiation of CD4 $4^{+} \mathrm{T}$ cells to Th17 cells $[19,25]$. Previous studies have also shown that 17 strains of Clostridia and $B$. fragilis support the induction and proliferation of Tregs that produce IL-10 $[9,41]$. Interestingly, we observed a contrasting correlation between the Clostridia and Bacteroidia classes, in that after anastomotic surgery they decreased while IL- $10^{+}$Treg numbers increased. These differences again could be due to the timing of post-operative collection and what type of surgery was performed.

Post-operatively, we observed that the Th17, and iNKTh17 populations had a higher expression of TCR $\beta$ than control non-surgical mice. TCR upregulation can occur when the cells are preparing for mitosis or even independent of cell division $[27,46]$. It has been proposed that enhancement of TCR expression level overall is directly linked to $\mathrm{T}$ cell activation, this is so that the $\mathrm{T}$ cell sensitivity is elevated to peptide antigen [45]. Lastly, ceramide is known to induce TCR upregulation [45]. After mesenteric ischemic/reperfusion injury, ceramide concentration levels were increased in intestinal vasculature and coating the membranes of bacteria [17]. Ceramide is known to be involved in the host response to bacterial infections $[17,54,55]$. Therefore, the increased TCR expression that we observed after anastomotic surgery on Th17 and iNKTh17 cell populations could be due to long stimulation and a change in bacterial populations and ceramide levels, but this awaits further exploration.

Characterizing conventional DCs (cDCs) has led to intense debates and broad investigations. The issue is that several of the markers used to define DCs are also expressed by macrophages, including CD45, CD11c, CD11b, and MHC class II (IA-E). However, macrophages do not express the integrin $\alpha_{\mathrm{E}}$ chain $\mathrm{CD} 103$ $[5,35,38,50] . \mathrm{CD} 103^{+}$DCs are typical migratory cells in the lamina propria that have mainly been divided into two populations, $\mathrm{CD}_{11 \mathrm{~b}^{+}} \mathrm{CD}_{103^{+}}$and $\mathrm{CD} 11 \mathrm{~b}^{-}$ $\mathrm{CD}_{103^{+}} \mathrm{cDCs}$ [35]. For this reason, it was unexpected to us to find an increase in a new $\mathrm{CDC}$ population, CD11b $\mathrm{b}^{\text {hi }}$ $\mathrm{CD} 103^{\text {mid }}$, within all of the intestinal segments after anastomosis surgery. This novel population appeared to be a shift away from the $\mathrm{CD} 11 \mathrm{~b}^{+} \mathrm{CD}_{103^{+}} \mathrm{CDC}$ population as these cells decreased significantly after surgery. Now it is unknown whether there are distinct precursors

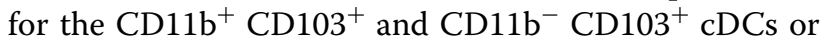
even what signals they obtain from the intestinal environment that leads to their final differentiation state [35]. Therefore, our data indicates that a post-operative environment leads to a new $\mathrm{CD} 11 b^{\text {hi }} \mathrm{CD} 103^{\text {mid }}$ DC differentiated population. Additionally, of the cDC populations, the $\mathrm{CD} 11 \mathrm{~b}^{\mathrm{hi}} \mathrm{CD} 103^{\text {mid }}$ DCs were expressing IL-10, an anti-inflammatory cytokine. It is known that activated $\mathrm{CD}_{11 \mathrm{~b}}{ }^{+}$DCs in the Peyer's patches produce higher levels of IL-10 than splenic DCs and are better able to activate $\mathrm{CD} 4^{+} \mathrm{T}$ cells to produce higher levels of IL-4 and IL-10 [10, 11]. CD103 ${ }^{+}$DCs, but not CD103 DCs, from the lamina propria are also known for being able to induce FoxP3 in naive $\mathrm{T}$ cells better than splenic DCs in the presence of exogenous TGF $\beta[10,11]$. Our post-operative results showed an increase in IL- $10^{+}$ CD11b ${ }^{\text {hi }}$ CD103 ${ }^{\text {mid }}$ DCs, which then correlated with an increase in TCR $\beta^{\text {hi }} \mathrm{CD} 4^{+} \mathrm{T}$ cells and Treg cells. These Treg cells had increased expression of IL-10 and IL-22, which are important for healing pathways [25]. Along with the IL- $10^{+}$Treg population increase, there was an increase in iNKT IL- $10^{+}$cells post-operatively. CD11c ${ }^{+}$ DCs can regulate iNKT cell homeostasis and activation via CD1d-dependent presentation of intestinal lipids [42]. This DC-iNKT cell crosstalk is important for controlling the bacteria and immune cell populations, such as Tregs within the intestinal compartment as mice with a CD1d conditional deletion have dysbiosis and altered immune homeostasis [42]. Importantly, $\mathrm{Cre}^{+} \mathrm{CD} 1 \mathrm{~d}^{\mathrm{fl} / \mathrm{fl}}$ $\mathrm{CD} 11 c^{\mathrm{Cre}}$ mice orally administered the lipid iNKT activator $\alpha$ GalCer had failed to increase Treg populations in the intestinal mesenteric lymph node whereas WT mice had increased Treg populations [42].

\section{Conclusions}

This study defines the microbiota and immune processes that take place to during anastomotic healing. By understanding which microbiome populations that are lost and how this may affect the induction and differentiation of immune populations, we can then target post-operative therapeutic treatments that allow for suitable and accelerated healing.

\section{Supplementary Information}

The online version contains supplementary material available at https://doi. org/10.1186/s13099-021-00447-z.

Additional file 1: Figure S1. Relative abundance of class and order bacterial groups change due to either anastomotic surgeries. (A) Relative abundance composition of the intestinal microbiome class or (B) order for each intestinal segment (top heading) within each surgery group ( $\mathrm{x}$-axis label).

Additional file 2: Figure S2. Expression of IL-10 and IL-22 in iNKT cells after end-to-end and Roux-en-Y anastomoses. (A) Dot plots showing increased IL-10+ expression in iNKT cells after both anastomotic surgeries. (B) Normalized iNKT cells that are $\mathrm{IL}-22^{+} .{ }^{*}=p \leq 0.05, \mathrm{n}=5-8$.

Additional file 3: Figure S3. Treg gating and expression of $\mathrm{IL}-10$ and IL-22. (A) Dot plots showing Treg cells after (A) no surgery, (B) end-to-end anastomosis, and (C) Roux-en-Y anastomosis from segment A. FoxP3 vs. TCR $\beta$ dot plots ( $2^{\text {nd }}$ column from top to bottom) back gate to either 
TCR $\beta^{\text {hi }} C D 4^{+}, \mathrm{TCR}^{\mathrm{hi} /+} \mathrm{CD} 4^{+}$, or TCR ${ }^{+} \mathrm{CD} 4^{+}$gates in the first dot plot. $\mathrm{IL}-22$ and IL-10 plots are back gated to the TCR $\beta^{\text {hi/ } /+} \mathrm{CD}^{+} \mathrm{FoxP}^{+}$parent plot. Representative of one experiment, $\mathrm{n}=6-7$.

Additional file 4: Figure S3. Treg gating and expression of IL-10 and IL-22. (A) Dot plots showing Treg cells after (A) no surgery, (B) end-to-end anastomosis, and (C) Roux-en-Y anastomosis from segment A. FoxP3 vs. TCR $\beta$ dot plots (2nd column from top to bottom) back gate to either TCRßhi CD4+, TCR $\beta$ hi/ + CD4+, or TCR $\beta+C D 4+$ gates in the first dot plot. IL-22 and IL-10 plots are back gated to the TCRßhi/+ CD4+ FoxP3+ parent plot. Representative of one experiment, $n=6-7$.

Additional file 5: Figure S4. Immune cell populations correlate to Bacteroidetes with distinct patterns based on either anastomotic surgery. Correlation graphs of (A) iNKT (TCR $\beta+$ CD1dtet + ) IL-22+ cells, (B) iNKT IL-10+, (C) CD11 bhi CD103mid DCs (CD45+ IA-IE+ CD110+), (D) Th17 (TCRßhi CD4+ IL-17A+ IL17F+) and (E) Treg (TCRß+ CD4+ FoxP3+) versus Bacteroidetes within surgery type.

Additional file 6: Figure S5. Immune cell populations correlate to Proteobacteria with distinct patterns based on either anastomotic surgery. Correlation graphs of (A) iNKT (TCR $\beta+$ CD1dtet+) IL-22+ cells, (B) iNKT IL-10+, (C) CD11 bhi CD103mid DCs (CD45+ IA-IE+CD110+), (D) Th17 (TCRßhi CD4+ IL-17A+ IL17F+) and (E) Treg (TCRß+ CD4+ FoxP3+) versus Proteobacteria within surgery type.

Additional file 7: Figure S6. Immune cell populations correlate to Bacteroidetes with distinct patterns based on surgical segments. Correlation graphs of (A) iNKT (TCRB+CD1dtet+) IL-22+ cells, (B) iNKT IL-10+, (C) CD11 bhi CD103mid DCs (CD45+ IA-IE+CD110+), (D) Th17 (TCRßhi CD4+ IL-17A+ IL17F+) and (E) Treg (TCR + CD4+ FoxP3+) versus Bacteroidetes within surgical segments.

Additional file 8: Figure S7. Immune cell populations correlate to Proteobacteria with distinct patterns based on surgical segments. Correlation graphs of (A) iNKT (TCRß ${ }^{+}$CD1 dtet ${ }^{+}$) IL-22 $2^{+}$cells, (B) iNKT IL-10

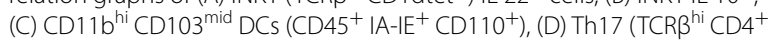
$\left.\mathrm{IL}-17 \mathrm{~A}^{+} \mathrm{IL} 17 \mathrm{~F}^{+}\right)$and $(\mathrm{E})$ Treg $\left(\mathrm{TCR} \beta^{+} \mathrm{CD} 4^{+}\right.$FoxP3 $\left.3^{+}\right)$versus Proteobacteria within surgical segments.

Additional file 9: Table S1. Pearson correlation coefficients ( $r$ ) for immune cell population versus phylums within anastomoses segments. Bolded $r$ value with * have a $p \leq 0.05$ and indicates a significant correlation between the immune cell population and phylum within that surgical segment.

Additional file 10: Table 2. Pearson correlation coefficients $(r)$ for immune cell population versus phylums within surgery types. Bolded $r$ value with * have a $p \leq 0.05$ and indicates a significant correlation between the immune cell population and phylum within that type of surgery.

\section{Acknowledgements}

The authors would like to thank Danielle Perley for her contributions to the microbiome sequencing analysis and to Dr. Shahram Solaymani-Mohammadi for help in editing this manuscript.

\section{Authors' contributions}

$\mathrm{ED}$ and $\mathrm{MB}$ contributed to the conception and design of the work. ED and AS contributed to the acquisition and analysis of the work. ED interpretated the data. ED drafted the manuscript. All authors read and approved the final manuscript.

\section{Funding}

Research reported in this publication was supported by the National Institute of General Medical Sciences of the National Institutes of Health under Award Number P20GM113123. The content is solely the responsibility of the authors and does not necessarily represent the official views of the National Institutes of Health. Flow cytometry research reported in this publication was supported by the Institutional Development Awards (IDeA) from the National Institute of General Medical Sciences of the National Institutes of Health under grant number P20GM103442 and P20GM1113123.

\section{Availability of data and materials}

Supplemental figures and tables are uploaded at https://doi.org/10.6084/m9. figshare.13645880 and link https://figshare.com/s/c485e4b8ea555cb4cd02. The metagenomics for the microbiome sequencing was uploaded to Bioproject with accession number PRJNA700677.

\section{Declarations}

\section{Ethics approval and consent to participate}

Not applicable.

\section{Consent for publication}

Not applicable.

\section{Competing interests}

The authors declare that they have no competing interests.

\section{Author details}

${ }^{1}$ Department of Surgery, University of North Dakota School of Medicine and the Health Sciences, 1301 North Columbia Road, Stop 9037, Grand Forks, ND 58202, USA. ${ }^{2}$ Department of Biomedical Sciences, University of North Dakota School of Medicine and the Health Sciences, 1301 North Columbia Road, Stop 9037, Grand Forks, ND 58202, USA. ${ }^{3}$ Department of Pathology, University of North Dakota School of Medicine and the Health Sciences, 1301 North Columbia Road, Stop 9037, Grand Forks, ND 58202, USA.

Received: 19 April 2021 Accepted: 30 July 2021

Published online: 10 August 2021

\section{References}

1. Abreu MT. Toll-like receptor signalling in the intestinal epithelium: How bacterial recognition shapes intestinal function. Nat Rev Immunol. 2010;10:131-43.

2. Alam A, Neish A. Role of gut microbiota in intestinal wound healing and barrier function. Tissue Barriers. 2018. https://doi.org/10.1080/21688370. 2018.1539595.

3. Amir A, McDonald D, Navas-Molina JA, Kopylova E, Morton JT, Zech XuZ, Kightley EP, Thompson LR, Hyde ER, Gonzalez A, Knight R. Deblur rapidly resolves single-nucleotide community sequence patterns. mSystems. 2017. https://doi.org/10.1128/msystems.00191-16.

4. An D, Oh SF, OlszakT, Neves JF, Avci FY, Erturk-Hasdemir D, Lu X, Zeissig S, Blumberg RS, Kasper DL. Sphingolipids from a symbiotic microbe regulate homeostasis of host intestinal natural killer T cells. Cell. 2014;156:12333. https://doi.org/10.1016/j.cell.2013.11.042.

5. Bain CC, Scott CL, Uronen-Hansson H, Gudjonsson S, Jansson O, Grip O, Guilliams M, Malissen B, Agace WW, Mowat AMI. Resident and proinflammatory macrophages in the colon represent alternative contextdependent fates of the same Ly6C hi monocyte precursors. Mucosal Immunol. 2013;6:498-510. https://doi.org/10.1038/mi.2012.89.

6. Bokulich NA, Kaehler BD, Rideout JR, Dillon M, Bolyen E, Knight R, Huttley GA, Gregory CJ. Optimizing taxonomic classification of marker-gene amplicon sequences with QIIME 2's q2-feature-classifier plugin. Microbiome. 2018. https://doi.org/10.1186/s40168-018-0470-z.

7. Caporaso JG, Kuczynski J, Stombaugh J, Bittinger K, Bushman FD, Costello EK, Fierer N, Pẽa AG, Goodrich JK, Gordon JI, Huttley GA, Kelley ST, Knights D, Koenig JE, Ley RE, Lozupone CA, McDonald D, Muegge BD, Pirrung M, Reeder J, Sevinsky JR, Turnbaugh PJ, Walters WA, Widmann J, Yatsunenko T, Zaneveld J, Knight R. QIIME allows analysis of high-throughput community sequencing data. Nat Methods. 2010;7:335-6.

8. Cerovic V, Bain CC, Mowat AM, Milling SWF. Intestinal macrophages and dendritic cells: what's the difference? Trends Immunol. 2014;35:270-7.

9. Chistiakov DA, Bobryshev YV, Kozarov E, Sobenin IA, Orekhov AN. Intestinal mucosal tolerance and impact of gut microbiota to mucosal tolerance. Front Microbiol. 2014. https://doi.org/10.3389/fmicb.2014.00781.

10. Coombes JL, Powrie F. Dendritic cells in intestinal immune regulation. Nat Rev Immunol. 2008;8:435-46. 
11. Coombes JL, Siddiqui KRR, Arancibia-Cárcamo CV, Hall J, Sun CM, Belkaid Y, Powrie F. A functionally specialized population of mucosal CD103+ DCs induces Foxp3+ regulatory T cells via a TGF- $\beta$-and retinoic aciddependent mechanism. J Exp Med. 2007;204:1757-64. https://doi.org/10. 1084/jem.20070590.

12. Devine AA, Gonzalez A, Speck KE, Knight R, Helmrath M, Lund PK, Azcarate-Peril MA. Impact of ileocecal resection and concomitant antibiotics on the microbiome of the murine jejunum and colon. PLOS ONE. 2013. https://doi.org/10.1371/journal.pone.0073140.

13. Dowds CM, Blumberg RS, Zeissig S. Control of intestinal homeostasis through crosstalk between natural killer T cells and the intestinal microbiota. Clin Immunol. 2014;159:128-33. https://doi.org/10.1016/j.clim. 2015.05.008.

14. Frosali S, Pagliari D, Gambassi G, Landolfi R, Pandolfi F, Cianci R. How the intricate interaction among toll-like receptors, microbiota, and intestinal immunity can influence gastrointestinal pathology. J Immunol Res. 2015. https://doi.org/10.1155/2015/489821.

15. Fujimoto K, Karuppuchamy T, Takemura N, Shimohigoshi M, Machida T, Haseda Y, Aoshi T, Ishii KJ, Akira S, Uematsu S. A new subset of CD103+CD8a+ dendritic cells in the small intestine expresses TLR3, TLR7, and TLR9 and induces Th1 response and CTL activity. J Immunol. 2011;186:6287-95. https://doi.org/10.4049/jimmunol.1004036.

16. Goodyear AW, Kumar A, Dow S, Ryan EP. Optimization of murine small intestine leukocyte isolation for global immune phenotype analysis. J Immunol Methods. 2014;405:97-108. https://doi.org/10.1016/j.jim.2014. 01.014 .

17. Hoehn RS, Seitz AP, Jernigan PL, Gulbins E, Edwards MJ. Ischemia/reperfusion injury alters sphingolipid metabolism in the gut. Cell Physiol Biochem. 2016;39:1262-70. https://doi.org/10.1159/000447831.

18. Hyman N, Manchester TL, Osler T, Burns B, Cataldo PA. Anastomotic leaks after intestinal anastomosis: it's later than you think. Ann Surg. 2007;245:254-8. https://doi.org/10.1097/01.sla.0000225083.27182.85.

19. Ivanov II, Atarashi K, Manel N, Brodie EL, Shima T, Karaoz U, Wei D, Goldfarb KC, Santee CA, Lynch SV, Tanoue T, Imaoka A, Itoh K, Takeda K, Umesaki Y, Honda K, Littman DR. Induction of intestinal Th17 cells by segmented filamentous bacteria. Cell. 2009;139:485-98. https://doi.org/ 10.1016/j.cell.2009.09.033.

20. Jakubzick C, Bogunovic M, Bonito AJ, Kuan EL, Merad M, Randolph GJ. Lymph-migrating, tissue-derived dendritic cells are minor constituents within steady-state lymph nodes. J Exp Med. 2008;205:2839-50. https:// doi.org/10.1084/jem.20081430.

21. Katoh K, Standley DM. MAFFT multiple sequence alignment software version 7: improvements in performance and usability. Mol Biol Evol. 2013;30:772-80. https://doi.org/10.1093/molbev/mst010.

22. Koch S, Nusrat A. The life and death of epithelia during inflammation: lessons learned from the gut. Annu Rev Pathol Mech Dis. 2012;7:35-60.

23. Lapthorne S, Pereira-Fantini PM, Fouhy F, Wilson G, Thomas SL, Dellios NL, Scurr M, O'Sullivan O, Paul Ross R, Stanton C, Fitzgerald GF, Cotter PD, Bines JE. Gut microbial diversity is reduced and is associated with colonic inflammation in a piglet model of short bowel syndrome. Gut Microbes. 2013. https://doi.org/10.4161/gmic.24372.

24. Lipska MA, Bissett IP, Parry BR, Merrie AEH. Anastomotic leakage after lower gastrointestinal anastomosis: men are at a higher risk. ANZ I Surg. 2006;76:579-85. https://doi.org/10.1111/j.1445-2197.2006.03780.x.

25. Longman RS, Littman DR. The functional impact of the intestinal microbiome on mucosal immunity and systemic autoimmunity. Curr Opin Rheumatol. 2015;27:381-7. https://doi.org/10.1097/BOR.0000000000 000190.

26. Love MI, Huber W, Anders S. Moderated estimation of fold change and dispersion for RNA-seq data with DESeq2. Genome Biol. 2014. https://doi. org/10.1186/s13059-014-0550-8.

27. Mamalaki C, Norton T, Tanaka Y, Townsend AR, Chandler P, Simpson E, Kioussis D. Thymic depletion and peripheral activation of class I major histocompatibility complex-restricted T cells by soluble peptide in T-cell receptor transgenic mice. Proc Natl Acad Sci USA. 1992;89:11342-6. https://doi.org/10.1073/pnas.89.23.11342.

28. Manichanh C, Rigottier-Gois L, Bonnaud E, Gloux K, Pelletier E, Frangeul L, Nalin R, Jarrin C, Chardon P, Marteau P, Roca J, Dore J. Reduced diversity of faecal microbiota in Crohn's disease revealed by a metagenomic approach. Gut. 2006;55:205-11. https://doi.org/10.1136/gut.2005.073817.
29. McMurdie PJ, Holmes S. Phyloseq: an R package for reproducible interactive analysis and graphics of microbiome census data. PLoS ONE. 2013. https://doi.org/10.1371/journal.pone.0061217.

30. Morse BC, Simpson JP, Jones YR, Johnson BL, Knott BM, Kotrady JA. Determination of independent predictive factors for anastomotic leak: analysis of 682 intestinal anastomoses. Am J Surg. 2013;206:950-6. https://doi. org/10.1016/j.amjsurg.2013.07.017.

31. Murrell ZA, Stamos MJ. Reoperation for anastomotic failure. Clin Colon Rectal Surg. 2006;19:213-6. https://doi.org/10.1055/s-2006-956442.

32. Nieuwenhuis EES, Matsumoto T, Lindenbergh D, Willemsen R, Kaser A, Simons-Oosterhuis Y, Brugman S, Yamaguchi K, Ishikawa H, Aiba Y, Koga Y, Samsom JN, Oshima K, Kikuchi M, Escher JC, Hattori M, Onderdonk AB, Blumberg RS. Cd1d-dependent regulation of bacterial colonization in the intestine of mice. J Clin Invest. 2009;1 19:1241-50. https://doi.org/10. $1172 / J C l 36509$.

33. Olszak T, An D, Zeissig S, Vera MP, Richter J, Franke A, Glickman JN, Siebert R, Baron RM, Kasper DL, Blumberg RS. Microbial exposure during early life has persistent effects on natural killer T cell function. Science. 2012;336:489-93. https://doi.org/10.1126/science.1219328.

34. Parks OB, Pociask DA, Hodzic Z, Kolls JK, Good M. Interleukin-22 signaling in the regulation of intestinal health and disease. Front Cell Dev Biol. 2016. https://doi.org/10.3389/fcell.2015.00085.

35. Persson EK, Scott CL, Mowat AM, Agace WW. Dendritic cell subsets in the intestinal lamina propria: ontogeny and function. Eur J Immunol. 2013;43:3098-107. https://doi.org/10.1002/eji.201343740.

36. Price MN, Dehal PS, Arkin AP. FastTree 2-approximately maximumlikelihood trees for large alignments. PLoS ONE. 2010. https://doi.org/10. 1371/journal.pone.0009490.

37. Rakoff-Nahoum S, Paglino J, Eslami-Varzaneh F, Edberg S, Medzhitov R. Recognition of commensal microflora by toll-like receptors is required for intestinal homeostasis. Cell. 2004;118:229-41. https://doi.org/10.1016/j. cell.2004.07.002.

38. Rivollier A, He J, Kole A, Valatas V, Kelsall BL. Inflammation switches the differentiation program of Ly6chi monocytes from antiinflammatory macrophages to inflammatory dendritic cells in the colon. J Exp Med. 2012;209:139-55. https://doi.org/10.1084/jem.20101387.

39. Rognes T, Flouri T, Nichols B, Quince C, Mahé F. VSEARCH: a versatile open source tool for metagenomics. PeerJ. 2016. https://doi.org/10.7717/peerj. 2584.

40. Round JL, Mazmanian SK. The gut microbiota shapes intestinal immune responses during health and disease. Nat Rev Immunol. 2009;9:313-23.

41. Round JL, Mazmanian SK. Inducible Foxp3+ regulatory T-cell development by a commensal bacterium of the intestinal microbiota. Proc Natl Acad Sci USA. 2010;107:12204-9. https://doi.org/10.1073/pnas.09091 22107.

42. de Guinoa SJ, Jimeno R, Gaya M, Kipling D, Garzón MJ, Dunn-Walters D, Ubeda C, Barral P. CD 1d-mediated lipid presentation by CD 11c+ cells regulates intestinal homeostasis. EMBO J. 2018. https://doi.org/10.15252/ embj.201797537.

43. Sakr A, Emile SH, Abdallah E, Thabet W, Khafagy W. Predictive factors for small intestinal and colonic anastomotic leak: a multivariate analysis. Indian J Surg. 2017;79:555-62. https://doi.org/10.1007/ s12262-016-1556-0.

44. Salio M, Silk JD, Yvonne Jones E, Cerundolo V. Biology of CD1- and MR1restricted T cells. Annu Rev Immunol. 2014;32:323-66.

45. Schrum AG, Turka LA, Palmer E. Surface T-cell antigen receptor expression and availability for long-term antigenic signaling. Immunol Rev. 2003;196:7-24.

46. Schrum AG, Wells AD, Turka LA. Enhanced surface TCR replenishment mediated by CD28 leads to greater TCR engagement during primary stimulation. Int Immunol. 2000;12:833-42. https://doi.org/10.1093/ intimm/12.6.833.

47. Selvanantham T, Lin Q, Guo CX, Surendra A, Fieve S, Escalante NK, Guttman DS, Streutker CJ, Robertson SJ, Philpott DJ, Mallevaey T. NKT celldeficient mice harbor an altered microbiota that fuels intestinal inflammation during chemically induced colitis. J Immunol. 2016;197:4464-72. https://doi.org/10.4049/jimmunol.1601410.

48. Sommovilla J, Zhou Y, Sun RC, Choi PM, Diaz-Miron J, Shaikh N, Sodergren E, Warner BB, Weinstock GM, Tarr PI, Warner BW. Small bowel resection induces long-term changes in the enteric microbiota of mice. J Gastrointest Surg. 2014;19:56-64. https://doi.org/10.1007/s11605-014-2631-0. 
49. Sun CM, Hall JA, Blank RB, Bouladoux N, Oukka M, Mora JR, Belkaid Y. Small intestine lamina propria dendritic cells promote de novo generation of Foxp3 T reg cells via retinoic acid. J Exp Med. 2007;204:1775-85. https://doi.org/10.1084/jem.20070602.

50. Tamoutounour S, Henri S, Lelouard H, de Bovis B, de Haar C, van der Woude CJ, Woltman AM, Reyal Y, Bonnet D, Sichien D, Bain CC, Mowat AM, Reis e Sousa C, Poulin LF, Malissen B, Guilliams M. CD64 distinguishes macrophages from dendritic cells in the gut and reveals the Th1-inducing role of mesenteric lymph node macrophages during colitis. Eur J Immunol. 2012;42:3150-66. https://doi.org/10.1002/eji.201242847.

51. Vargas-Caraveo A, Sayd A, Robledo-Montaña J, Caso JR, Madrigal JLM, García-Bueno B, Leza JC. Toll-like receptor 4 agonist and antagonist lipopolysaccharides modify innate immune response in rat brain circumventricular organs. J Neuroinflammation. 2020;17:1-17. https://doi.org/ 10.1186/s12974-019-1690-2.

52. Vomhof-DeKrey EE, Lansing JT, Darland DC, Umthun J, Stover AD, Brown C, Basson MD. Loss of SIfn3 induces a sex-dependent repair vulnerability after 50\% bowel resection. Am J Physiol Liver Physiol. 2021;320:G136-52. https://doi.org/10.1152/ajpgi.00344.2020.
53. Wingender G, Stepniak D, Krebs P, Lin L, McBride S, Wei B, Braun J, Mazmanian SK, Kronenberg M. Intestinal microbes affect phenotypes and functions of invariant natural killer T cells in mice. Gastroenterology. 2012;143:418-28. https://doi.org/10.1053/j.gastro.2012.04.017.

54. Zhang Y, Li X, Carpinteiro A, Gulbins E. Acid sphingomyelinase amplifies redox signaling in pseudomonas aeruginosa-induced macrophage apoptosis. J Immunol. 2008;181:4247-54. https://doi.org/10.4049/jimmu nol.181.6.4247.

55. Zhang Y, Li X, Grassmé H, Döring G, Gulbins E. Alterations in ceramide concentration and $\mathrm{pH}$ determine the release of reactive oxygen species by Cftr-deficient macrophages on infection. J Immunol. 2010;184:510411. https://doi.org/10.4049/jimmunol.0902851.

56. Zundler S, Tauschek V, Neurath MF. Immune cell circuits in mucosal wound healing: clinical implications. Visc Med. 2020;36:129-36.

\section{Publisher's Note}

Springer Nature remains neutral with regard to jurisdictional claims in published maps and institutional affiliations.
Ready to submit your research? Choose BMC and benefit from:

- fast, convenient online submission

- thorough peer review by experienced researchers in your field

- rapid publication on acceptance

- support for research data, including large and complex data types

- gold Open Access which fosters wider collaboration and increased citations

- maximum visibility for your research: over $100 \mathrm{M}$ website views per year

At BMC, research is always in progress.

Learn more biomedcentral.com/submissions 